\title{
Deep Help in Complex Project Work: Guiding and Path-Clearing Across Difficult Terrain
}

\section{Citation}

Fisher, Colin M., Julianna Pillemer, and Teresa M. Amabile. "Deep Help in Complex Project Work: Guiding and Path-Clearing Across Difficult Terrain." Harvard Business School Working Paper, No. 18-035, October 2017.

\section{Permanent link}

http://nrs.harvard.edu/urn-3:HUL.InstRepos:34334597

\section{Terms of Use}

This article was downloaded from Harvard University's DASH repository, and is made available under the terms and conditions applicable to Open Access Policy Articles, as set forth at http:// nrs.harvard.edu/urn-3:HUL.InstRepos:dash.current.terms-of-use\#OAP

\section{Share Your Story}

The Harvard community has made this article openly available.

Please share how this access benefits you. Submit a story.

Accessibility 


\section{Deep Help in Complex Project Work: Guiding and Path-Clearing Across Difficult Terrain}

Colin M. Fisher Julianna Pillemer Teresa M. Amabile

Working Paper 18-035 


\title{
Deep Help in Complex Project Work: Guiding and Path-Clearing Across Difficult Terrain
}

\author{
Colin M. Fisher
}

University College London

Julianna Pillemer

University of Pennsylvania

Teresa M. Amabile

Harvard Business School

Working Paper 18-035 
DEEP HELP IN COMPLEX PROJECT WORK:

GUIDING AND PATH-CLEARING ACROSS DIFFICULT TERRAIN

\author{
Colin M. Fisher \\ University College London \\ colin.fisher@ucl.ac.uk \\ Julianna Pillemer \\ University of Pennsylvania \\ pillemer@wharton.upenn.edu
}

Teresa M. Amabile

Harvard University

tamabile@,hbs.edu

\title{
Acknowledgements
}

We would like to thank Scott Sonenshein and three anonymous reviewers for their deep and thoughtful help throughout this process. We are also extremely grateful to Spencer Harrison, Mike Pratt, Martin Kilduff, Erin Reid, Emily Heaphy, Michelle Barton, Bess Rouse, Brigham Hall, UCL Reading Group, Wharton Impact Lab, and GroupsGroup for their input and feedback on earlier versions of this research. We gratefully acknowledge the funding support of the Harvard Business School Division of Research and Faculty Development. We would also like to thank our wonderful informants at GlowDesign, without whom this research would not have been possible. 


\title{
DEEP HELP IN COMPLEX PROJECT WORK: GUIDING AND PATH-CLEARING ACROSS DIFFICULT TERRAIN
}

\begin{abstract}
How do teams working on complex projects get the help they need? Our qualitative investigation of the help provided to project teams at a prominent design firm revealed two distinct helping processes, both characterized by deep, sustained engagement that far exceeds the brief interactions described in the helping literature. Such deep help consisted of (1) guiding a team through a difficult juncture by working with its members in several prolonged, tightly clustered sessions, or (2) path-clearing by helping a team address a persistent deficit via briefer, intermittent sessions throughout a project's life. We present a model theorizing these processes, which has two noteworthy features. First, it emphasizes the socially constructed nature of helping behavior. That is, the parties must establish and maintain a helping frame for their interaction, especially when help-givers are high-status external leaders. Second, the model specifies that the rhythms of deep help — the duration and temporal patterns of giver-receiver interactions - are resource-allocation decisions that also contribute to the social meaning of help. These findings illuminate the theoretical and practical overlap between helping and external leadership in knowledge-intensive project work, and the role of temporality in the helping process.
\end{abstract}

Keywords: helping, rhythm, prosocial behavior, external team leadership, social construction, groups and teams, time, qualitative methods, field research

Running Header: Deep Help 


\section{DEEP HELP IN COMPLEX PROJECT WORK:}

\section{GUIDING AND PATH-CLEARING ACROSS DIFFICULT TERRAIN}

A complex, knowledge-intensive project is like a mountain hike over difficult terrain, where the way forward is hidden from view. It is unwise for individuals to make such journeys alone. Indeed, contemporary organizations typically use teams for projects aimed at generating new ideas and solving difficult problems (Cohen and Bailey, 1997; Wuchty, Jones, and Uzzi, 2007). For such teams, useful and timely external help can mean the difference between success and failure (e.g., Ancona \& Caldwell, 1992; Fisher, 2017). However, getting genuinely helpful help can be difficult when teams are overwhelmed by the ambiguities of a project and the pressure to complete it. They may struggle to assess the quality of their work in progress (Alvesson, 2001), or to specify what knowledge and skills they need to successfully complete the project (Long Lingo \& O’Mahony, 2010). They may not even realize they need help. It may also be quite difficult for outsiders to understand the team's situation in enough depth to provide assistance, especially when the team itself is confused.

Prior research on helping has focused on the antecedents and consequences of helpseeking (e.g., Bamberger, 2009) and help-giving (e.g., Flynn, 2006). In general, helping is associated with better organizational performance (e.g., Podsakoff et al., 2009), team effectiveness (e.g., MacKenzie, Podsakoff and Ahearne, 1998), and collective creativity (e.g., Hargadon and Bechky, 2006). But helping also entails costs for both givers and receivers. For givers, help deflects time and attention away from their own work (e.g., Flynn, 2006); for receivers, help can reveal weakness and create a sense of indebtedness (e.g., Lee, 2002).

The actual process of giving and receiving help has thus far gone largely unexplored, because providing help has been viewed as a relatively simple act. To be sure, help may be 
straightforward when it consists merely of quick favors and advice (e.g., Borgatti \& Cross, 2003;

Flynn \& Lake, 2008) but helping in a context of knowledge-intensive team projects may be more complex. Project teams often encounter unforeseen obstacles (Morgeson, 2005) and confront significant ambiguities throughout their work (Long Lingo \& O’Mahony, 2010). Little is known about how external helping unfolds in these complex collaborative settings (Morgeson, Derue, \& Karam, 2010; cf. Grodal, Nelson, \& Siino, 2015). Thus, the field is ripe for a theoretical framework that details the helping process - the temporal dynamics of the event sequences that constitute help (e.g., Hernes, Simpson, \& Söderlund, 2013; Langley \& Tsoukas, 2017).

Adopting a process perspective (Langley, 1999), we carried out a qualitative study of the help received by project teams at GlowDesign (hereafter called Glow), a leading design consultancy that specializes in complex knowledge-intensive projects. All names of individuals and companies in this paper are pseudonyms). Our initial aim was to develop a process theory of how help happens in complex project-based work; we expected to investigate the sort of brief helping interactions addressed in existing research. In the course of collecting data, however, we were surprised by the extent to which help with a given issue encompassed multiple encounters and prolonged time commitments from help-givers. In fact, we discouraged informants from reporting cases that exceeded a single meeting between the help-giver and help-receivers (hereafter called givers and receivers) until we realized that many informants viewed these episodes as especially significant cases of helping.

We ultimately came to view such interactions as the most theoretically and practically interesting phenomenon, which we call deep help —intensive, repeated assistance in which givers (typically high-status external leaders) devote considerable time to helping teams with especially difficult problems. After identifying deep help as a pervasive phenomenon in this organizational 
context, we focused our analyses on the question: How does the deep-help process unfold in the context of complex project work? Addressing this question enables us to venture beyond theories of the conventional (brief, one-time) helping process (e.g., Grodal et al., 2015) and to highlight how the helping process can be shaped by the temporal rhythm of interactions (i.e., their duration and pattern) and by givers' and receivers' social construction of the meaning of those interactions.

\section{THEORETICAL BACKGROUND}

\section{Helping in Organizations}

Organizational scholars conceptualize helping as a prosocial, interpersonal behavior (e.g., Bolino \& Grant, 2016; LePine, Erez, \& Johnson, 2002) whereby one party (the giver) allocates time and attention to a second party (the receiver) with the intent of providing benefit (Bamberger, 2009; Grant and Patil, 2012). Helping encompasses such diverse activities as quick favors (e.g., Flynn \& Lake, 2008), problem-solving advice (e.g., Perlow \& Weeks, 2002), and emotional support (e.g., Toegel, Kilduff, \& Anand, 2013). Feedback about performance (Harrison \& Rouse, 2015) can be a component, but help must go beyond feedback to include assistance in achieving the receivers' goals.

The breadth of theoretical conceptualizations of helping notwithstanding, empirical research has largely focused on brief, one-time helping interactions (cf. Golan \& Bamberger, 2015). Help-giving and help-receiving of this type serves multiple functions: enabling the perspectives of givers and receivers to collide in "fleeting moments" (Hargadon \& Bechky, 2006: 485); developing givers' and receivers' knowledge and skills (Perlow \& Weeks, 2002); and serving as a problem-solving routine (Grodal et al., 2015). These findings demonstrate that 
one-time interactions, ranging in length from under a minute to almost an hour (Grodal, 2014, personal communication; Hargadon \& Bechky, 2006), can rapidly shift receivers' focus, equip them to incorporate outside perspectives, and provide resources for emergent needs.

But how helping extends beyond brief, one-time interactions - the kind of helping that we heard about repeatedly at Glow — is unknown. Given the complexity of work in contemporary knowledge-intensive organizations (e.g., von Nordenflycht, 2010), receivers may need to interact with a single giver in long, concentrated sessions, or repeatedly across a project's lifespan on tasks with differing durations, making help more complex than described in existing research. Because knowledge workers generally avoid rigid bureaucracy, management in such contexts tends to be informal, with ill-defined hierarchical lines of accountability (e.g., von Nordenflycht, 2010; Kellogg et al., 2006). These fluid and flexible hierarchical structures increase the chances that organizations can meet emergent needs (e.g., Brown and Eisenhardt, 1997; Katz \& Kahn, 1978), but they can also inhibit coordination. In flatter organizations, it is less clear who is responsible for addressing problems as they arise. Teams may thus be uncertain about who to approach when they need help, and potential helpers may be uncertain about how and where to allocate their time and attention. These considerations increase the ambiguity facing project teams and those who support them, a scenario that suggests a need for more in-depth understanding of how these processes unfold in knowledge-intensive organizations.

Moreover, people working on complex projects may struggle to describe the help they need, or fail to recognize that they need help at all. Research on helping in such ambiguous and confusing situations is scant. Most helping research examines situations in which receivers seek help purposefully (e.g., Hofmann, Lei, \& Grant, 2009; Bamberger, 2009) and potential givers decide whether to help in response to an explicit request (cf. Deelstra et al., 2003), such as asking 
strangers to participate in a survey (Flynn \& Lake, 2008) or asking coworkers for small favors or advice (Perlow \& Weeks, 2002). Thus, a critical but unstudied component of helping in complex project work is how both givers and receivers identify whether teams need help, what help they need, and when they need it.

In addition, members of organizations often have different perceptions of whether a given interaction should be regarded as "help", as opposed to simply being part of one's organizational role (e.g., Toegel et al., 2013) or an unwanted burden or intrusion (Perlow \& Weeks, 2002). These divergent perceptions may be heightened when roles are ambiguous and progress unclear. Thus, in our inquiry, we paid special attention to how meanings are constructed through social interaction (Collins, 2004; Gergen \& Gergen, 1983; Goffman, 1967), and how these constructed meanings may in turn shape the helping process itself.

In sum, the literature on helping in organizations has established the importance of providing teams with external help, but has not fully explicated how such assistance unfolds. Existing research has also largely assumed that those in need of assistance recognize and articulate those needs. These conditions often go unmet in the kinds of complex projects that increasingly characterize creating and managing knowledge in organizations.

\section{METHOD}

We conducted an inductive, multi-method field study at GlowDesign. Design firms are known for complex project work and for unusually high levels of helping (Hargadon \& Bechky, 2006; Sutton \& Hargadon, 1996); this setting enabled us to collect data on both prototypical and extreme helping cases (Eisenhardt, 1989). Glow is a well-known design consultancy founded in the early 1990s. Hundreds of employees work at its offices in North America, Europe, and Asia; roughly half are headquartered in California. Glow provides client organizations a range of 
services, including product design, brand development, and strategy consulting. In the words of an internal document, Glow assigns teams to create solutions that are "desirable, feasible, and viable."

Figure 1, like Harrison and Rouse's (2015) description of the interplay between data collection and analysis in qualitative research, summarizes how we proceeded through three rounds of data collection (each focused on a different method), analysis, and theory development. We will first describe our initial round of data collection and the insights we gained about the organizational context and the role of helping at Glow. We will then turn to Rounds 2 and 3 of data collection and the analyses that produced our main findings.

[Insert Figure 1 here]

\section{Round 1 Data Collection}

Data collection began with on-site observation and informal interviews at a Glow office in a large U.S. East Coast city. Our goals were to acquire an understanding of the Glow context and of the types of help that occurred there (see Figure 1, Round 1). Our early conversations with firm partners and administrative staff helped us identify an initial set of informants likely to provide frequent help. We then experimented with interview protocols and conducted a pilot version of the critical-incident interview used in Round 3 with five of the most sought-after givers.

Developing questions and rough contours of themes. In analyzing our Round 1 data, we met weekly to discuss themes, questions, and data-collection strategies. We also solicited feedback on preliminary insights from Glow informants, who helped refine Round 2 and Round 3 methods.

\section{The Organizational Context and Helping at Glow}


The Glow process. Glow projects typically lasted 5-22 weeks and consisted of a maximum of three stages. During Stage 1 (Research/Strategy), teams conducted research by observing and interviewing users of analogous products and services. A team redesigning a diaper, for instance, studied rapid backstage costume changes during theatrical productions. In Stage 2 (Design), teams worked to translate what they had heard and observed into "frameworks, opportunities, solutions, and prototypes" (internal Glow document). In Stage 3 (Delivery), they developed detailed procedures and engineering protocols for final prototypes.

Project teams at Glow. Glow teams typically consisted of 2-5 core members, one of whom served as the Project Lead (PL). Each team included experts in diverse specialties, such as human factors, business, and engineering; regardless of functional background, all core team members were considered designers. Team members typically worked on a given project from beginning to end, and pursued only one project at a time. Each team worked in a dedicated project space, which its members customized with pertinent photos, drawings, and products.

Helping norms at Glow. Glow's cooperative ethos was very strong from the outset: in the words of a company document distributed to all employees, Glow's founder envisioned an organization that "feels like working with friends." Helping norms were a natural manifestation of this vision. As the company handbook declared: "Making others successful is the mother lode of all Glow values - genuinely wanting success for others and going out of your way to help them get there is the secret sauce." Giving help to other project teams was expected of all but the most junior designers. "Helping is everybody's job at Glow, and it is very much part of the culture," one senior leader told us. "It's everybody's job and therefore it's nobody's job" (G01). ${ }^{1}$

\footnotetext{
${ }^{1}$ Informants are identified as givers $(\mathrm{G})$ or receivers (R) of help and are assigned unique identifying numbers used throughout the manuscript.
} 
We routinely observed individuals external to a project team giving its members time and attention in the forms of brainstorms, design reviews, and serendipitous meetings in the halls.

Organizational structure and external leadership at Glow. Help givers were often firm leaders, who typically exercised more control over their own schedules and were not assigned to specific project teams. Glow's organizational structure was relatively flat, and strong norms deemphasized differences in status. Even the internal manual that described job titles downplayed the importance of hierarchy:

The hierarchical model [of management] limits opportunities for personal engagement, discovery, and connection. ... At Glow, there is no single person who can give permission or specific direction for you to follow. Instead, there exist multiple points of influence and leadership you need to connect in order to put a plan into action.

Thus Glow was largely non-hierarchical and highly reliant on self-managing teams.

Status differences did exist, however, and all employees could readily identify partners, design directors, and area leads. Moreover, Glow leaders were expected to assist teams, but these expectations were typically implicit rather than explicit: the responsibilities of a team's Project Lead and core members were clearly defined, but the nature of Glow leaders' involvement was not. Newly formed teams were encouraged to connect with an informal "extended team" of senior employees that usually included the client contact (a partner, area lead, or businessdevelopment lead) and at least one senior designer with relevant functional experience. This arrangement created a discomfiting tension for many leaders: though their help was somewhat expected and highly valued, the form it should take was often unclear. One area lead explained:

Two words that Glow is very uncomfortable with are "responsibility" and "authority." What do we have responsibility for, and what do we have authority over? No one wants to talk about that, and it just means that it's very fluid. (G02)

On any given project, therefore, extended team members enacted their role very differently: some never interacted with the team while others did so frequently. 


\section{Round 2 and Round 3 Data Collection and Analysis}

Round 2 data collection. To capture "the complex 'tango' between help-seekers and potential providers" (Bamberger, 2009: 88), we used daily diaries coupled with weekly interviews (see Figure 1, Round 2, for details). Guided by key informants, we sought out teams whose projects varied in length, types of deliverables, and team members' backgrounds and experience. We selected only teams whose members all agreed to participate in our research. Table 1 describes the teams and the data collected from them.

\section{[Insert Table 1 here]}

To collect diary entries, we sent each team member a text message at the end of each workday. Their brief responses described (a) work they had performed on the project that day; (b) what help, if any, they had received from Glow employees external to the team; and (c) ratings of how helpful those interactions had been (on a 7-point Likert scale). At the end of each week the second author conducted a private semi-structured interview with each team member and each repeat help-giver ${ }^{2}$; the interviews, which lasted 10-45 minutes, explored in more detail the help received or given that week. (See Appendix A for the interview protocol.) By the end of data collection on our final two teams, we found that we were no longer capturing new information about variations in helping cases. We thus concluded that we had reached theoretical saturation (Eisenhardt, 1989) and did not recruit additional teams.

Preliminary analyses of Round 2 data. We met regularly to discuss themes that had emerged in Round 2. For each of the four projects, we compiled a project summary focused on the role of helping in the project. We shared our insights in debriefings with three of the teams, whose members variously verified, elaborated on, and corrected our interpretations.

\footnotetext{
${ }^{2}$ Repeat help-givers are those mentioned in multiple helping episodes described in the team's diaries. Help-givers were not asked to keep daily diaries.
} 
Round 3 data collection. To further investigate the themes that had emerged, we next explored which aspects of the helping process prompted informants to deem an episode a good or poor example of helping. We also conducted a targeted search for extreme cases. To do so, we conducted 25 more critical-incident interviews (Flanagan, 1954; McClelland, 1998) over a fourday period at the firm's largest office, to supplement the five we had collected during Round 1. We again worked with liaisons at Glow to select informants representative of a range of functions, experience levels, and demographic characteristics.

Informants could choose whether to report incidents of giving help or of receiving help. We asked informants to identify and describe two critical incidents: one in which they believed themselves to have been especially helpful or to have received especially valuable help, and a second in which they tried to help but felt unhelpful or received help that was unhelpful. (See Appendix B for the interview protocol.) Interviews lasted around 90 minutes; seven respondents who had limited time reported only one case in sufficient detail. Figure 1, Round 3, provides more detail on the data collected.

Formal analyses and disciplined theorizing. To begin our main data analyses, the first and second authors independently performed open coding of thoughts, behaviors, and contexts from field notes, diaries, and interview transcripts; at weekly meetings, all three authors discussed how to aggregate the codes to produce higher-order theoretical dimensions (Gioia, Corley, \& Hamilton, 2013; Locke, 2001). We also coded the temporal elements of our data (Langley, 1999), such as whether behaviors were pre-interaction, during interaction, or postinteraction. We used these temporal-process categories to structure a 1-2-page summary memo about each set of giver-team interactions. The structure of concepts, and examples of key concepts, will appear in Tables 3, 4, and 5. 
Early in the analytic process, we encountered a difficulty that led us to theorize deep help: we were struggling to define the boundaries of a helping episode. In keeping with the literature, we initially defined an episode as a single encounter. We soon found that our informants did not always share that conceptualization; they often described interactions that consisted of multiple encounters, lasting days or even weeks. This pattern led us to abandon our attempts to focus on detailed single-interaction descriptions. Mapping patterns of help across multiple encounters between the same giver and receiver revealed processes of helping that differed from those previously described in the literature. To refine our theorizing (Locke, 2001), we conducted additional interviews at Glow to compare our insights with employees' perceptions.

Deep help. The remainder of this paper focuses solely on cases of intensive, repeated assistance, which we call deep help. We identified such cases using three criteria. First, either the giver or the receiver, or both, had to identify the interaction as characterized by helping. Second, the giver had to meet with the receiver(s) more than once during the project. Third, the help could not be of a kind not formally specified in advance as a responsibility of the help-giver. ${ }^{3}$ The first and second authors independently identified such cases from Round 2 and Round 3 data collection. All three authors then made a final determination that 27 cases (14 from Round 2 diaries and interviews, 13 from Round 3 critical incident interviews) fit the definitional criteria for deep help. Each of the 27 deep-help cases is described in Table 2.

[Insert Table 2 here]

\section{FINDINGS}

\footnotetext{
${ }^{3}$ Occasionally a team would hire an internal or external contractor to perform technical work, such as graphic design, or electrical engineering. Though such contractors often interacted with the team for hours or days on end, their tasks and roles were well defined from the start, and we do not view these cases as deep help. 
Our most noteworthy finding was that teams at Glow received crucial support via deep help - intensive, repeated assistance in which givers spend substantial time assisting teams with especially difficult problems. We use a hiking metaphor to explain deep-helping processes: a team undertaking a complex project resembles a climb in uncertain, difficult terrain. Glow teams received deep help via two different processes, which we call guiding and path-clearing. Guiding and path-clearing differ not only in their content but also in their rhythms, or the duration and pattern of helping interactions over the course of the project. Figure 2 describes the four team projects and provides examples of these two deep-helping rhythms.

[Insert Figure 2 here]

The differences between the guiding and path-clearing rhythms are illustrated in Figure 2. Guiding features several prolonged encounters that are tightly clustered together in calendar time; path-clearing interactions tend to be shorter and more intermittent. The two cases of deep help provided to Team Canadian Health Works illustrate these differences well. The project's two-member team was working to craft a new strategy for a large nonprofit health-care organization. (See Figure 2 for a more detailed description of the team and its issues.) Illustrative of the guiding rhythm, Anna, the PL (C3-R06), ${ }^{4}$ scheduled three successive two-hour sessions with Violet (C3-G05) at the point of transition between research and design, a juncture widely viewed at Glow as one of the trickiest in a project's life. In the path-clearing case, by contrast, Brad (C19-G03) helped the team sporadically throughout the project, in such varied ways as driving members to a research site and advising them on dealing with the client; no single episode lasted longer than 90 minutes. Givers like Violet and Brad might cumulatively spend comparable amounts of time interacting with a team over the course of the project, but the

\footnotetext{
${ }^{4}$ When a quotation is drawn from a case described in Table 2, the case is referenced in the identification number. For instance, C19-G03 indicates Case 19, Giver 03.
} 
rhythms of their respective involvements were tailored to addressing different issues in very different ways.

Because deep help is time-intensive, it was provided predominantly by such high-level Glow leaders as partners, design directors, and area leads, who were not assigned full-time to projects and thus exercised more control over their own schedules. We conceptualize these highstatus outsiders as providing external leadership to Glow teams (e.g., Manz \& Sims, 1987). The two deep-help processes, including their phases and sub-processes, are depicted as mountain treks in Figure 3, and are described in more detail in subsequent sections.

[Insert Figure 3 here]

\section{Surveying}

To begin either of the two deep-helping processes, givers and receivers need to identify the issues and agree that they warrant extensive time commitments. This initial phase, which we call surveying, is depicted at the bottom center of Figure 3. Table 3 presents additional examples of the constructs related to surveying discussed below.

[Insert Table 3 here]

Two sources of information helped potential givers identify issues requiring deep help. First, givers leveraged their own prior knowledge about the team, the project, and/or the client. Each Glow site was small enough for most employees to know everyone else and be familiar with most current projects. For example, Ed (C16-G16), a senior designer, had led a past project for a given client. When a new project for the same client was staffed, Ed was uneasy about the team's inexperience: “It's a pretty green team and a pretty tough client, which is just not a good mix." Prior knowledge of team members' degree of experience and awareness of a project's 
demands prompted potential givers to pay attention to particular teams, and informed how they interpreted subsequent observations of the project and interactions with the team.

Givers also gleaned information by observing artifacts in the project space. Teams were encouraged to display visual representations of their thinking at all stages; thus a quick glance at a project space conveyed information about the project's status. Ron (C6-G04), a senior designer, described his impressions of a team's progress based on observation of artifacts and awareness of the project's stage of development: "I was able to walk in and see a few foam-core boards that [made it] clear that they didn't have enough concepts to actually make something." Thus both the array of artifacts and how it was displayed enabled potential external helpers to discern a team's status, even if its members could not specify their needs. In combination with prior knowledge, potential givers use artifacts to make inferences about how a project is progressing and whether the team might need help.

Receivers also participated actively in the surveying process, shaping givers' interpretations of a project and a team's issues. Directly requesting deep help was rare: it was too much to ask of high-status outsiders, and many receivers were unaware that deep help was available. But requests for feedback and/or conventional help (such as advice and small favors) conveyed their thoughts and feelings about their projects' issues, leading givers to revisit their prior knowledge and observations. For example, Linda (C11-G02), a senior designer, recounted a request articulated in a chance conversation with a Project Lead: "[The PL and I] ride the same subway home. ... [I asked him], 'Are you having fun?' [and he said,] 'No, I'm having a horrible time. Maybe you could come help.'... He was so miserable-looking, totally miserable." Linda had already been uneasy about the project but had not intervened. Prior to the PL's request, she told us, "I honestly did not feel very emotionally invested in having this project be a raging 
success." In this instance, as in other cases of deep help, a receiver request enlightened a potential giver about the issues facing the project and their severity, prompting further action in the form of deep help.

As for team members, describing problems and expressing distress was not merely passive venting but an effort to communicate and even amplify the depth of their needs, evoking heightened commitment and concern from potential givers. Aaron (C2-R01) described asking a partner for advice (which eventually led to deep help): "It was both an act of looking for help and, also, it was a strategic political action on my side. I'm not going to hide this [problem] from him. I'm going to expose it to him right away and see if he reacts negatively or he really helps us." Receivers might feel uncomfortable asking for deep help directly, but most were able to shape givers' perceptions of the team's issues and needs by how they described the issue and their own feelings about it: their framing of the problem and its emotional impact informed potential givers' perceptions of its seriousness and elicited deeper involvement. Givers' prior knowledge and observations thus function in tandem with receivers' sense-giving and emotional expressions to indicate which of the two deep-helping processes might be appropriate. As Figure 3 illustrates, the two deep-helping processes diverge at this point; we will discuss guiding and path-clearing separately below.

\section{Guiding}

At times, teams needed someone to accompany or lead them across a particularly difficult juncture. Such help, which we call guiding, entails delving deeply into a single issue over the course of several multi-hour interactions clustered closely together in time. (See the ascending 
path on the left-hand side of Figure 2.) Table 4 presents key concepts in guiding along with examples.

[Insert Table 4 here]

Identifying issues. The guiding process was typically triggered by the perception that the team had reached a critical juncture - a difficult, temporally delimited interval characterized by a heightened need for assistance. Critical junctures typically occurred at transitions between phases, often occasioned by client presentations (and, sometimes, complaints about them) and abrupt shifts in teams' activities and mindsets. For instance, teams frequently needed outside guidance at the point of transition between research and design, which Glow designers called synthesis (see Figure 2, C3-G05 and C8-G05). As one designer explained: "Synthesis is always what we at Glow call the most uncomfortable, foggiest part of the creative process, because you don't know what you're going to end up with.... You're not going to get there in two minutes; you're not going to get there in two days" (C1-G06). When givers and receivers agreed that a team had reached this "foggy" juncture, they knew that it would require more than a few minutes of attention. To be truly helpful, givers needed to wade into the project more deeply.

Adopting a rhythm. To enable guiding at a critical juncture, givers and receivers had to spend a significant interval interacting intensively. They mutually recognized that this process had to be scheduled; both givers and receivers often rearranged their calendars to accommodate it. For example, Russell (G07), a partner, described offering to help a team work out how to appease a disgruntled client:

I'm realizing now I'm along for the ride on this thing. So I'm going to try and clear my schedule for the next week as much as possible, so I can spend four hours a day with that team. Otherwise I'm going to kind of be like an extra client for them, someone who doesn't quite get it but has an opinion — not that helpful. Not that helpful. (G07) 
Because a guiding interaction addresses a single complex issue, it lasts longer than a typical 60-minute meeting. And because the work performed is intense, it is usually broken up into multiple sessions clustered over a short span of days. The intensity and tight clustering of the guiding rhythm enables a giver to understand the project deeply enough to address complex issues in close collaboration with the team. If the meetings were shorter, the giver could easily become little more than "an extra client," only roughly aware of what the team is struggling with; if the meetings were spread out over time, the project might change so much in the interim that the giver would need to be reoriented to the project. Thus adopting a guiding rhythm enables the specific form of help that the receivers need most.

Establishing a helping frame. Adopting a guiding rhythm can send an ambiguous social signal to receivers. On the one hand, allocating so much time suggests that a high-status giver cares about the team and their problem. On the other hand, the giver's intense involvement threatens their autonomy: in lengthy, tightly clustered meetings, a guide can easily take control of parts of the project, supplanting the team's ideas — "hacking the project" (C15-R02), as one receiver put it. Such a large allocation of time may also imply that a giver believes the receivers to be incapable of handling the problem on their own, threatening receivers' self-esteem.

How givers communicated their intentions at the outset, and how receivers perceived those intentions, were critical to moving the guiding process forward. We call these communications and perceptions establishing the helping frame; it is depicted in Figure 3 as simultaneous with adopting the guiding rhythm. In Case 2, for example, Gary was careful to emphasize that he would not supplant Aaron as a leader. As Aaron later recounted, Gary said, "I'll come to New York just to spend that week with you guys. And I can take off of your plate some of the pressure of the project work. So, I'm going to be your crutch. I'm not here to change 
the project; I'm just here to help you." Aaron said this message made him feel "very supported" (C2-R01). For a firm partner to travel cross-country to work with them could easily have alarmed the team-especially the project leader. But Gary was proactive both about allocating more time than Aaron could have asked for and about framing that time as helping — serving as a crutch, rather than what Aaron characterized as "that imposing partner figure." Such actions clarify the giver's role and reassure receivers, imbuing their interactions with a positive social meaning.

The guiding rhythm also had a scheduled endpoint, which reassured receivers that givers would not attempt to take over the project. In Case 2, Gary arranged to arrive Tuesday and depart Friday, a schedule that gave the team confidence that he was not seeking to supplant Aaron's leadership; $2-3$ days would be insufficient for Gary to implement changes himself. Thus, his role was to enable the team to forge ahead on its own.

Mapping. Because guiding addresses complex and ambiguous issues, the path forward may initially be unclear to both givers and receivers. Their shared sense of the teams' quandary kicks off the mapping phase, during which receivers provide the giver a deeper and more specific orientation to the team's task and its members' thoughts and feelings about it. The resulting shared understanding will enable the guide and the team to co-discover a path forward in later phases. Mapping begins at the outset of the giver's scheduled time with the team. Allocating several long blocks of time allows givers to immerse themselves in the project for hours or even days, a process that one receiver called "steeping in the project" (R04). Initially, the giver is relatively passive, asking questions and listening intently. For example, Violet (C3-G05) spent three days with Canadian Health Works (see Figure 2). She later observed that the "early help was mostly coming in and listening to what they had." In conventional help, both parties know that the interaction will be brief; therefore, receivers must take care not to "try to tell them 
[helpers] everything, but this one thing" (G06). By contrast, a guide adopts a slower pace, taking in the team's situation in full and gradually homing in on core issues. This process equips the guide to help identify needs that the team may not initially articulate (and may even be unaware of) and to co-create customized approaches to meeting those needs with receivers.

Reinforcing the helping frame. To proceed beyond mapping, a giver first must confidently grasp the project's aims and its issues. For instance, Linda described guiding a project whose technical content she did not fully understand; even so, she was confident that she could help the team generate a framework for synthesizing that content:

There was just too much talking and not enough drawing and playing with ideas.... It was clear, even though I didn't know about the content, that they had no idea how to synthesize it. That was the thing I felt most on solid ground about. (C11-G02)

Linda had pinpointed the central problem: the team's inability to organize information. This sense of "solid ground" was her cue to begin to range through the issue with the team.

For receivers to follow a guide, in turn, they must believe that the giver genuinely understands and appreciates their work. The time that a giver spends listening and asking questions during mapping helps create an air of understanding, but givers also conveyed their understanding explicitly. Sean, a designer, described how a design director made him feel understood during the mapping process: "[The giver] would ask me questions like, 'What are you really trying to say here?' He made sure that he understood it. He kind of acknowledged and appreciated where I'd gotten to with it" (R04). In order to move on to ranging, both givers and receivers need to develop a metacognitive sense of mutual understanding that reinforces the helping frame: the giver needs to understand the project; the receivers need to be certain that the giver understands. This shared understanding allows the process to move forward within the helping frame, as the giver begins to assert more influence. 
Ranging. Ranging, the active help-giving phase, begins when a guide suggests and facilitates a new approach to the transition the team faces. In Case 1, Hazel adopted a more active role halfway through her second day with the team, once she and its members sensed that she had steeped sufficiently. She then suggested an approach she called "the triangle framework":

I brought in a framework that I've used before, and I drew that up on the board and said, "Why don't we take some of these insights [that the team had articulated] and start applying them to this framework and see where it takes us?". . . Putting that framework up, it was like a catalyst. ... The lightbulbs went on, and we were able to make that leap from foggy insights to "Oh, now we can get generative and create ideas." (C1-G06)

Hazel guided team members by leading a process for organizing and combining their field research findings and ideas for moving forward. Only after a day and a half of mapping - to fully understand the team's thinking and figure out how she might help them move it forwarddid she suggest the framework. Guiding typically concentrates on suggesting processes that teams can use to navigate a tricky transition, not on the project's specific content. In other words, a guide only shows the way toward the summit; the receivers do the actual hiking.

Ending the process. Once the team has adopted the new approach, or the allotted time has elapsed, the guiding process ends. When they perceive the path to follow, receivers are eager to reassert their autonomy and continue their work. Simultaneously, the giver needs to hand control back to the team; dependence on the giver could further disrupt the schedule and undermine team functioning. In Case 10, for example, Linda observed a change in the team's behavior and affect after she suggested and led several exercises to ease their struggles with Synthesis:

The fact that [the team] seriously pushed back was a great sign. Now they agreed on something. This is amazing! And they told me I was wrong, and that was great. . . [Later] there was this silence, and I said, "Do we need to continue this?" And they said no. And I was like, "Should I just walk out?" [The team said,] "Yeah, we have a plan 
now. We don't need to talk more. We can start to really figure out what this means." So I just walked out because they felt good, and what's the point in staying? (C10-G02)

As Linda had observed, the team's initial issue - that its members were not integrating their separate perspectives - was resolving. The team was eager to move on once its trajectory was clear, and Linda's presence prevented them from doing so. This realization led both parties to end the interaction, with a shared sense of accomplishment and progress. Whether as a result of receivers' reassertion of autonomy or expiration of the allotted time, ending the guiding process enabled teams to continue their climb alone without feeling threatened or intruded on.

Process deviations. In most cases, the guiding process proceeded as described above. However, two attempts at guiding deviated significantly (see Table 2, Cases 15 and 16). In both cases, the parties struggled to manage the tension between receivers' autonomy and their potential dependence (e.g., Nadler, 1987; Nadler, 2015): high-status givers took control of important aspects of teams' projects, crowded out their ideas, undermined their psychological ownership (Baer \& Brown, 2012; Rouse, 2016), and provoked strongly negative affective reactions. We call such scenarios takeovers. For example, in Case 15 the Project Lead, Carole, requested help from Richard, the senior designer who managed the client relationship; he had just returned from vacation. Carole recalled:

When we went into the project space to write, I thought it would just be evaluating the text that we'd already written. ... Richard took the laptop and started typing what he thought [the content] would be. And so it turned into his content, not the team's. . . . Richard hacked the project content and stepped on my toes. (C15-R02)

Instead of guiding Carole and her teammates to address the problem he perceived, Richard took the request for help as an invitation (or opportunity) to exert control over the project. Richard later took over leadership of the client presentation, displacing Carole. This episode led Carole to question not merely the value of seeking help but also her own identity as a designer: "I felt like 
I wasn't able to illustrate my own skills. I felt like he took that away from me.... That wasn't my project in the end. It's like someone else did it." (C15-R02)

As this case illustrates, two process mechanisms that are essential to guiding are absent in takeovers. First, the receivers and the giver do not establish and reinforce a helping frame. In this case, Carole expected feedback and advice (though she was not explicit about this expectation in her request) rather than content revision. Also, in both takeovers the mapping phase was extremely brief and the receivers felt that the givers had misunderstood the issue entirely. Second, in neither case did the parties formally schedule end points. Thus, the receivers had no guarantee that the high-status giver would respect the team's autonomy. As Carole told us, she felt obligated to accept Richard's involvement: "This is what I should do because he's the practice person; he's the relationship with the client." The lack of an explicit schedule left the team without a safeguard when a high-status giver took more control over the project than they wanted.

\section{Path-Clearing}

The second deep-helping process is path-clearing: addressing a persistent deficit in multiple ways via semi-regular interactions throughout the duration of the project (see the righthand side of Figure 3). The path-clearing process can eliminate obstacles to the team's progress, enabling its members to focus on the project's content.

Identifying issues. Givers and receivers who pursued guiding perceived that a team had reached a critical transitional juncture; by contrast, those who pursued path-clearing construed the team's issues as ongoing and attributable to a mismatch between the team's resources (e.g., skills and time) and the project's demands - that is, a persistent deficiency. Such issues typically 
entailed inexperience and especially difficult projects. For instance, Ron explained why he was performing path-clearing for Team Medical Device: 'I've mostly been helping because it's Craig's first full-time Glow project" (C25-G04; see Figure 2). Table 5 presents examples of this and other central concepts in path-clearing.

[Insert Table 5 here]

Establishing the helping frame. Because path-clearing deals with issues that are common and persistent, path-clearers are initially less specific than guides about the precise roles they will play. At the outset they make only generalized offers of help. For instance, in Team Pharma Process, Wayne (C17-G08) agreed with the Project Lead, Violet (C17-R03), ${ }^{5}$ that the project's scope was too broad and ill-defined (see Figure 2). He thus made a generalized offer of help on Day 2 but waited for Violet to make a specific request: "I offered help . . at the beginning, and it took a while for Violet to figure out how she could use me. So I pretty much stayed back" (G08).

To underscore that they do not intend to impose themselves, givers wait for a specific request from receivers. Such a request moves the path-clearing process to the next phase. From Day 2 Violet knew of Wayne's availability to help; she told us at the time: "Wayne is going to play a bigger role going forward, I think, than he has so far" (C17-R03). But Violet did not make a request until Day 12. This delay enabled her to control the nature of the help that Wayne gave, though Wayne was a high-status designer she admired. Leaving it to the team to decide when to interact, and for what purpose, establishes a shared understanding of the helping frame, whereby givers can provide frequent assistance without causing the team to feel continuously monitored.

\footnotetext{
${ }^{5}$ Note that Violet, a help-receiver (R03) on Team Pharma Process, served as a giver of deep help (G05) to both Team Canadian Health Works and Team Medical Device (see Figure 2). 
Adopting a rhythm. In contrast to the scheduled, deliberate nature of the guiding rhythm, path-clearing rhythms are emergent and impromptu. Nevertheless, both parties expect that the giver will be intermittently involved, as exemplified by Violet's sense that Wayne was "going to play a bigger role going forward." Similarly, Ron (C25-G04) described his advice to Craig (C25R05), whose first Glow project was Team Medical Device:

I offered to help in general and Craig said, "Can you help me think about this [tool for conceptualizing the design]?" ... [After the initial interaction], I wouldn't say [the issue is] resolved. ... That thing is going to live on for a few weeks at least. . . Craig and I now pretty much have a standing agreement: "Hey, stop by when you have a chance." (C25G04)

Craig made a specific request, after which Ron stopped by briefly and frequently to offer advice and to find out if Craig had additional questions (see Figure 2). The path-clearing rhythmperiodic help to address an ongoing deficiency—enables receivers to make recurrent requests without having to repeatedly seek out an available giver and bring him or her up to speed.

Mapping and ranging. Guiding proceeds in a linear fashion from mapping to ranging; in path-clearing, by contrast, those two phases occur iteratively (see Figure 3, the upper portion of the right-hand path). Rather than trying to apprehend the project details first, path-clearers mapped a portion of it as they ranged and kept their eyes open for the next stretch of path to clear. We refer to this more limited mapping activity as looking ahead. The cycle began when givers fulfilled receivers' initial requests. For instance, Violet, the Project Lead on Team Pharma Process, described how Tony, the path-clearer, proactively sought additional information from the client on Day 22 after having advised the team the previous week:

Tony actually did a phone call with the technology person on the client side which was helpful because I didn't have to do it. ... He took the initiative. He found out about the call and he joined it. We really needed to be plugged into that stuff and it wasn't even on my radar! (C20-R03)

Tony's earlier assistance had equipped him to discern what further actions might be helpful. 
Thus, in path-clearing, the initial helping interaction not only aided the team but also served as a mapping expedition: the giver's information-gathering and sense-making then led to subsequent help—-help that the team, left to its own devices, would probably have missed.

Like Ron, Wayne, and Tony, path-clearers expect to "help in general," sporadically. At the outset, therefore, they are not merely fulfilling the initial request; they are also anticipating future obstacles. As if blazing a winding mountain trail after a storm, path-clearers expect obstacles even if they cannot foresee when or where they will appear. While clearing away an obstacle, they often glance up ahead at the next stretch. This process of routinely looking ahead creates a self-reinforcing feedback loop of crucial information for givers and renders assistance available for receivers. Wayne described his ranging activities with Team Pharma Process as "filling the holes" (C17-G08, Figure 2). His figure of speech captures the ethos of path-clearing: path-clearers react to problems as they emerge, either by providing more help or by recruiting others to do so, creating a virtuous cycle of assistance. The cycle continues as receivers consistently update the giver and make new requests, and as the giver finds new holes to fill and proactively fills them.

Reinforcing the helping frame. At Glow, both receivers and givers were acutely aware that helping can reveal weaknesses and expose receivers to criticism. The rhythm of pathclearing accentuated this dynamic. Givers checked in frequently over an extended span of time; if receivers felt increasingly monitored and evaluated, the helping frame could be damaged. Bill, a partner, explained how important it was to avoid this dynamic:

The challenge is not to go in there and create so much anxiety that you're in a worse spot than you were if you had just never walked in in the first place... . It can be like, "Here's the boss and, gosh, he's really unhappy with what we're doing, and now I'm demoralized." That happens, but you really want to avoid that. (G09)

Path-clearers reinforced the helping frame in two ways. First, they made themselves 
available to the team by stopping in frequently, either to report on prior help or to ask how things were going. (See Table 5 for examples.) Second, path-clearers often performed menial tasks that belied their high status. For instance, in Team Canadian Health Works, Brad (C19-G03) signaled that he was assisting in a supportive, non-supervisory capacity by driving the team to a client site (Day 1) and taking notes during an interview (Day 5). (See Figure 2 for more detail.) "Little things like that are really helpful; they add up," the PL, Anna (C19-R06), told us. "Sometimes you don't feel like you even have time to ask someone to do that for you." One team member speculated that, for Brad, his supportive acts were like elementary-school recess-a break from his normal managerial responsibilities (C19-R07).

Ending the process. In contrast to guiding, path-clearing lacks a scheduled endpoint to structure the interaction; path-clearing tends to end only when the project phase ends. At transitions between phases, projects are often re-staffed in ways that address anticipated team needs and therefore lessen the need for path-clearing. In some cases, moving to a new phase also means that different kinds of expertise are required. For instance, in Team Pharma Process, Amelia (C18-G10) helped as a path-clearer throughout the first two phases of the project but not in the final phase, which called for technical expertise that she lacked. The flexibility of pathclearing allows givers to adjust the help they provide in keeping with their own availability and expertise and the team's needs. Changes in teams' needs and givers' schedules thus typically determined when to end the path-clearing process. Alternatively, the signal to end the process could simply be the end of the project itself: for two of the four Round 2 teams, path-clearing continued nearly until the last day of the project. (See Figure 2, C25-G04 and C17-G08.)

Process deviations. Attempts at path-clearing did not always adhere to the essential elements of the process. Path-clearing progresses in an iterative fashion because givers learn 
about a project by pitching in, often with simple tasks, which can in turn reveal additional needs for path-clearing. In some cases that exhibited similar rhythms of interaction (e.g., Cases 26 and 27), givers failed to pitch in - to receivers' consternation. This outcome was usually due, at least in part, to the giver's failure to allocate sufficient time: he or she had set aside enough time to check in but not enough to understand the issues, remove an obstacle, or look ahead at possible future obstacles. At the extreme, path-clearers offered shallow criticism without constructively addressing issues or pointed out obstacles without helping remove them. Glow designers derided this scenario as a swoop-and-poop.

For example, over a four-week period Roger (C26-R08), the PL, received repeated feedback on a draft client report from the client's main contact at Glow. Roger's aim had been to elicit general design feedback and to keep the path-clearer informed in the hope that she might help later on. But instead of making a generalized offer and waiting for the team to identify a way for her to help, she volunteered to edit documents: “We didn't actually ask for her help; she volunteered it. ... She's like, 'Oh, I really love writing, and I'm good with grammar and spelling." Thus the process for establishing the helping frame was not followed. Over time the team found her attempts at help "distracting" to the point of labeling them "a full-on swoop-andpoop." Instead of performing menial tasks or anticipating what the team might need, she merely suggested editorial changes. Roger commented: "Either help me or get the fuck out of the way. . .. Don't undermine my confidence and then walk out of the room. ...You can't walk into a room, tell [us] that there's a stinking fish, and walk out."

Because of givers' high status at the firm, and because their behavior resembled (and sometimes included) genuine help, receivers usually felt obligated to continue to solicit their feedback, perpetuating swoop-and-poops. Roger elaborated: 
I felt there was a little awkwardness to it because, on the one hand, she is making a genuine substantive contribution [and] she owns the client relationship. . . . I was still relatively new and I didn't want to piss her off. (C26-R08)

Given Roger's reticence, the path-clearer was probably unaware of how her feedback had affected him. The status gap between firm leaders and team members helps explain why swoopand-poops, though counter-normative at Glow, can persist.

\section{DISCUSSION}

We began our investigation by asking how the helping process unfolds in complex project work. Like prior researchers, we initially assumed that such help would consist of brief, one-time interactions. Instead, Glow designers often described much more extensive helping interactions that spanned multiple episodes. In response to these unexpected findings, we theorized two forms of deep help that informants considered crucial to the functioning of their projects: (1) intensive, collaborative guiding to help teams through treacherous transitions in their projects' life spans, and (2) intermittent, multifaceted path-clearing to support a team handicapped by a persistent deficiency. This process model emphasizes the ongoing, socially constructed nature of helping behavior. It also illustrates how the rhythms of deep help entail resource-allocation decisions that also contribute to the social meaning of help. These findings reveal the theoretical and practical overlap between helping and external leadership in complex project work, and the role of temporality in the helping process.

\section{Theoretical Contributions}

Deep helping processes in organizations. This study extends and elaborates theory on helping in organizations in four ways. Most importantly, it expands the scope of helping theory 
beyond the initiation of brief, one-time helping episodes. Prior research has largely concentrated on whether people seek help when they need it (e.g., Bamberger, 2009) and whether those approached agree to provide help (e.g., Flynn, 2006), seldom specifying the nature or patterns of helping interactions (cf. Golan \& Bamberger, 2015). Further, studies of helping practices in organizations have focused on "fleeting moments" (e.g., Hargadon \& Bechky, 2006; Grodal et al., 2015) devoted to quick problem solving, favors, and advice. Our exploration of deep help shows that help can be much more complex: it can extend across multiple interactions, and does not always adhere to a single process. How the deep-helping process unfolds is an outgrowth of the issue identified: critical junctures call for intensive, concentrated guiding, whereas persistent deficiencies invite intermittent path-clearing. The existence of distinct helping process that span multiple interactions suggests new directions for research on help with specific issues, such as coping with unpleasant emotions (e.g., Toegel et al., 2013), interpersonal citizenship behaviors (Methot, Lepak, Shipp, \& Boswell, 2017), and making collective decisions (e.g., Fisher, 2017). Second, the surveying and mapping sub-processes reveal how givers and receivers collaborate to recognize and articulate the need for help. Prior research has tacitly assumed that a need for help is obvious - that receivers can recognize and articulate their needs clearly to potentially helpful others in their network (e.g., Nadler, Ellis, \& Bar, 2003), and that givers need only to decide whether to honor such requests (e.g., Flynn and Lake, 2008). In complex projects, however, it may be impossible to fully anticipate the capabilities that will be required. This complexity makes periods of hardship practically inevitable and paths forward so unclear or so volatile that team members may fail to grasp what help they need, or even to realize that they need help. In deep help, we found, the helping process can begin even before givers and receivers interact, and even in the absence of receivers' awareness that they need help. This 
suggests that help giving is dictated not only by who knows who, but also by how the help-givers recognize cries for help before deciding to intervene. These critical insights suggest that scholars abandon the assumptions that help-seekers have made thorough assessments of their own needs and that mere agreement to provide help is the main outcome of interest.

Third, our theorizing suggests that the social exchange model that underlies much of helping research (e.g., Flynn, 2006) may not apply well to flatter, knowledge-intensive organizations like Glow. Glow's strong helping norms (e.g., Grant and Patil, 2012) led givers to help because of what March and Olsen (2004) called "a logic of appropriateness", in which organizational identification motivates adherence to norms, even when the consequences of compliance (or noncompliance) are unclear. Beyond expectations of direct or reciprocated benefits, Glow employees' deep help-giving was motivated by a complex mixture of desires to enact their identities as designers (Elsbach and Flynn, 2013), to engage with projects and people (Grodal et al., 2015), and to fulfill a self-defined sense of their own in-role obligations (Morrison, 1994; Toegel et al., 2013). Future research should thus consider multiple, and simultaneous drivers of helping and other prosocial behaviors (Bolino \& Grant, 2016).

Fourth, this research suggests that help for complex projects in contemporary organizations is strongly linked to creativity - specifically, the creation of new knowledge. The surveying and mapping phases of the deep helping process are means of problem discovery, while ranging (especially in guiding) often involves a collaborative process of idea generation and idea evaluation. Thus, as theories of organizational creativity and innovation have become more dynamic (Amabile \& Pratt, 2016; Fisher \& Amabile, 2009) and boundary-crossing (PerrySmith \& Mannucci, 2017), so, too, must theories of helping expand to explicitly include subprocesses that shift as the needs of complex projects evolve. 
Deep help and external team leadership. Because givers of deep help at Glow were almost invariably high-status designers with leadership responsibilities, we conceptualize deep help as a process of providing teams with external leadership. This concept builds on prior research suggesting that interventions by external leaders have considerable conceptual overlap with helping. For instance, Morgeson (2005: 497) argued that "external team leadership is centered on helping teams solve the problems they encounter on a day-to-day basis." This view is consistent with both functional (e.g., Hackman \& Wageman, 2005; Kozlowski et al., 2016) and servant (e.g., Liden et al., 2014) approaches to team leadership.

In contemporary organizations, deep help may be a critical way to provide such external team leadership. Complex, knowledge-intensive projects with more fluid role definitions engender more ambiguity about who is responsible for what, blurring distinctions between helping, external leadership, and teamwork. This blurriness in turn intensifies the need for teams and external leaders to clarify the social meaning of their helping interactions. Rather than viewing helping and external leadership as separate phenomena, we adopt a social interactionist perspective (Collins, 2004; Goffman, 1967), arguing that "helping" is a socially constructed (rather than objective) property of a behavior (Gergen \& Gergen, 1983). A high-status member of an organization volunteering to spend several days with a team, or assisting a team with various tasks over a span of weeks, could have multiple meanings for givers and receivers. The action could be seen as a simple fulfillment of in-role obligations (e.g., Toegel et al. 2013). It could also be construed as a generous offer to assist, attesting to the importance of the project and/or team. Or it could be a devastating implied criticism of the team and its Project Lead, expressive of doubt about their capabilities. Because givers and receivers may not agree on the 
meanings they initially ascribe to an interaction (Morrison, 1994; Toegel et al., 2013), establishing and reinforcing a helping frame is an essential part of the deep-helping process.

The power and status of potential deep helpers makes the helping journey more treacherous, as evident in our findings about process deviations (i.e., takeovers and swoop-andpoops). Receiving help can both support and threaten self-esteem (Nadler, 1987; Nadler \& Halabi, 2006), and can feel "intrusive and manipulative" to team members when the givers are external leaders (Morgeson, 2005: 18; see also Manz \& Sims, 1987; Wageman, 2001). When external leaders try to address teams' critical junctures or persistent deficiencies without establishing a helping frame, they can elicit hostility rather than gratitude. Thus, deep involvement on the part of high-status outsiders is a double-edged sword: givers can use such involvement to monitor and control, not merely to support and assist. Establishing and reinforcing a helping frame is critical if receivers are to accept assistance, and deviating from the process can undermine even the best intentions. The helping process itself thus shapes whether givers' actions are seen as supporting or undermining receivers.

This social interactionist perspective on helping extends prior research that conceptualizes autonomy and dependence as objective characteristics of the particular kind of help provided; the classic example is the distinction between the contrast between offering a hungry man a fish dinner and teaching him to fish (e.g., Nadler, 2015). Our findings suggest that the same behavior can be construed as preserving or undermining autonomy depending on whether a helping frame is established and reinforced. For example, providing a fish dinner might be viewed as an autonomy-promoting form of help when it allows an individual to pursue more important goals than cooking. This insight also pertains to research on external team leadership, which has tended to view hands-on assistance as inherently undermining to team self- 
management (Manz \& Sims, 1987; Wageman, 2001), rather than dependent on the social meaning of the interaction.

Temporality. A process perspective on deep help contributes to research on temporality in two ways. First, it highlights the role of temporal rhythm - the duration and pattern of interactions - in shaping the two deep-helping processes. Building on the view that time and attention are finite organizational resources (e.g., Cummings and Haas, 2012; March and Simon, 1958), we argue that adoption of a deep-helping rhythm is a critical resource-allocation decision that transcends the potential giver's decision about whether to help. For givers, the decision to engage is not merely a question of whether to help; it is a nuanced calculation about how much time and attention to allocate. To receive deep help, in turn, teams too must divert their attention away from other activities, heightening the potential costs of receiving help.

Temporal rhythms also shape the social meanings of interactions. In guiding, the fixed duration of an episode acts as assurance that givers will ultimately restore receivers' autonomy. In path-clearing, the brevity of individual interactions and their intermittent rhythm prevent givers from becoming enmeshed enough in any issue to threaten autonomy. Nevertheless, external leaders can play a critical role in defining and maintaining the meaning of allocated time as either helping or micro-managing. This notion builds on recent research that finds allocation of temporal resources to be a critical leadership activity (Mohammed \& Nadkarni, 2011). Our findings suggest that framing the meaning of temporal resources is also a critical aspect of leadership, and that the nature of the time allocated can be used to establish and reinforce intentions to help.

By emphasizing rhythm's role in the helping process, we answer calls in organizational research for time-related theoretical constructs that transcend clock time (e.g., Ancona, 
Okhuysen, \& Perlow, 2001). Although temporal rhythms in organizations have occasionally been studied, in the forms of repetitive calendar cycles (e.g., Ancona and Chong, 1999; Zerubavel, 1985) and patterns of turn-taking in conversation (e.g., Collins, 2004; Goffman, 1967), we view temporal rhythms as an underused lens for understanding interactions in the context of deadline-driven projects. Such approaches could also be useful to study other collaborative or competitive social interactions in organizations, such as teamwork and negotiation.

\section{Limitations and Future Directions}

Three unusual features of Glow Design provided an extreme setting in which to study deep help. Jointly, these features suggest the boundary conditions of our findings. First, Glow's culture explicitly values helping to an unusual degree; most employees, including high-level leaders, seek out opportunities to give help. Second, Glow has adopted a relatively nonhierarchical structure and loose definitions of roles. Deep helpers may be scarce at organizations with rigid hierarchies and strictly defined duties; thus, deep help may be less common and framing interactions less necessary at such organizations. Third, all Glow projects are creative, in that they require a high degree of novelty as well as utility, raising the question of the extent to which our findings apply to less creative work. We propose that it is not the novelty of project work per se that creates the need for deep help, but its complexity and ambiguity. Future research should examine the extent of deep help in organizations beyond these boundary conditions, and the extent to which norms of helping, flat organizational structure, and project complexity interact to shape how outsiders address critical junctures and persistent deficiencies. 
Our data restricted our ability to analyze three aspects of deep help. First, we obtained limited information about the nature of interpersonal relationships between givers and receivers. Prior research suggests that the decision to help is not necessarily a purely rational choice to allocate attention to whoever needs it most. Instead, when and how deep helping occurs may be shaped by certain attributes of the relationship between giver and receiver, such as the quality of the relationship (e.g., Dutton \& Heaphy, 2003), leader-member exchanges (e.g., Graen \& UhlBien, 1995), and perceptions of trust (e.g., Hofmann, Lei, \& Grant, 2009). We observed several cases in which deep help was provided in the absence of a prior interpersonal relationship (i.e., Cases $2,8,25)$, but we did not systematically collect data on aspects of interpersonal relationships that may facilitate deep help. Future research should explore the role of such relationships in the deep-help phenomenon.

Second, future research should examine how multiple cases of deep help within a single project may interrelate. For example, it is likely that the team's experience of one case of deep help will shape its receptiveness to further deep help. In a single project, our data suggest, an early case of deep help can influence subsequent cases by changing the project content and eliminating the need to address a nagging issue. But we seldom observed deep-help givers coordinating with each other or, indeed, even attending to what others were doing. Nonetheless, coordination and interaction between cases of deep help should be possible, as should interaction with or displacement of conventional help. The mutual influence and interrelatedness of deephelping episodes, and the conditions under which each kind of deep help is most useful on its own, are promising directions for future research.

Finally, our methods did not entail much direct observation of the deep-helping interactions analyzed here; we relied instead on diaries and interviews. These data illuminate 
broad patterns of help, but may underplay the role of physicality and micro-processes in these interactions. Prior research has shown that physical space and tangible artifacts can contribute to overcoming discrepancies between people's knowledge and perspectives (e.g., Bechky, 2003; Carlile, 2004; Kellogg et al., 2006), like those between deep-help givers and receivers. Further, subtle emotional and cognitive cues may play a role in promoting mutual attention and engagement (e.g., Metiu \& Rothbard, 2013; Grodal et al., 2015). Future research should incorporate more direct observation to further unpack physicality and micro-processes in deep help. Moreover, our interview and diary methods focused on interactions between Glow employees, but minimized the information we had about interactions with clients and other outsiders; the possible role of such outsiders in deep help should be addressed in future research.

\section{Practical Implications and Conclusion}

Our model of deep help has several important implications for practice. First, simply being aware of guiding and path-clearing as possibilities can change the way teams and external leaders respond to serious problems in complex projects, encouraging people to engage in deep help when needed. Further, we hope our findings discourage practitioners from equating deep involvement with micro-management. Such a change in mindset should encourage external leaders to offer deep help, and teams to embrace these offers. For such changes to occur, however, organizations need take several actions to promote truly productive deep help: 1) give senior employees flexibility in their schedules, 2) communicate explicit norms and values around helping (Amabile, Fisher \& Pillemer, 2014; Grant \& Patil, 2012), and 3) train or otherwise encourage leaders to consider as-needed deep help to be part of their responsibilities. Such norms and communication should focus on leaders making their intention to help explicit by asking 
questions, listening, and, in path-clearing, performing menial tasks. Correspondingly, team members should communicate with potential help-givers about emergent and on-going issues, even when they are distressed and confused about exactly what help to request. Once deep helping has begun, help-givers should assiduously avoid take-overs and swoop-and-poops, which break the tenuous helping frame.

In the past, organizational scholars have been well-served by treating helping interactions as simple and brief, and as minor contributions to fulfilling key leadership functions. But as work becomes more complex and knowledge-intensive (Rousseau, 2004), organizations become flatter (Rajan \& Wulf, 2006), and projects become more collaborative, deep help may in turn become increasingly central to the accomplishment of crucial leadership functions. Indeed, deep help may be part and parcel of a broader trend away from hierarchical approaches to external leadership, a trend in which the social construction of interactions between individuals with loosely-defined roles takes center stage. By creating a helping frame for interactions, external leaders need not choose between enabling self-management and providing hands-on assistance; they can do both. In the course of investigating the helping process in complex knowledgeintensive project work, we found helping in organizations to be far more than favors or brief advice; helping can itself be a complicated and ambiguous task spanning multiple interactions. Helping and external leadership are complex social processes — not only destinations but also journeys across difficult terrain. 


\section{REFERENCES}

Alvesson, M. 2001. Knowledge work: Ambiguity, image and identity. Human Relations, 54: 863-886.

Amabile, T., Fisher, C. M., \& Pillemer, J. 2014. IDEO's culture of helping. Harvard Business Review, 92(1): 54-61.

Amabile, T. M., \& Pratt, M. G. 2016. The dynamic componential model of creativity and innovation in organizations: Making progress, making meaning. Research in Organizational Behavior, 36: 157-183.

Ancona, D., \& Chong, C. L. 1999. Cycles and synchrony: The temporal role of context in team behavior. In E. A. Mannix \& M. A. Neale (Eds.), Research on managing groups and teams: 33-48. Greenwich, CT: JAI Press.

Ancona, D. G., \& Caldwell, D. F. 1992. Bridging the boundary: External activity and performance in organizational teams. Administrative Science Quarterly, 37: 634-665.

Ancona, D. G., Okhuysen, G. A., \& Perlow, L. A. 2001. Taking time to integrate temporal research. Academy of Management Review, 26: 512-529.

Baer, M., \& Brown, G. 2012. Blind in one eye: How psychological ownership of ideas affects the types of suggestions people adopt. Organizational Behavior and Human Decision Processes, 118: 60-71.

Bamberger, P. 2009. Employee help-seeking: Antecedents, consequences and new insights for future research. In J. J. Martocchio \& H. Liao (Eds.), Research in personnel and human resources management, vol. 28: 49-98. Emerald Group Publishing Limited.

Bechky, B. A. 2003. Sharing meaning across occupational communities: The transformation of understanding on a production floor. Organization Science, 14: 312-330.

Bolino, M. C., \& Grant, A. M. 2016. The bright side of being prosocial at work, and the dark side, too: A review and agenda for research on other-oriented motives, behavior, and impact in organizations. Academy of Management Annals, 10: 599-670.

Borgatti, S. P., \& Cross, R. 2003. A relational view of information seeking and learning in social networks. Management Science, 49: 432-445.

Brown, S. L., \& Eisenhardt, K. M. 1997. The art of continuous change: Linking complexity theory and time-paced evolution in relentlessly shifting organizations. Administrative Science Quarterly, 1-34.

Carlile, P. R. 2004. Transferring, translating, and transforming: An integrative framework for managing knowledge across boundaries. Organization Science, 15: 555-568.

Cohen, S. G., \& Bailey, D. E. 1997. What makes teams work: Group effectiveness research from the shop floor to the executive suite. Journal of Management, 23: 239-290.

Collins, R. 2004. Interaction Ritual Chains. Princeton, NJ: Princeton University Press.

Cummings, J. N., \& Haas, M. R. 2012. So many teams, so little time: Time allocation matters in geographically dispersed teams. Journal of Organizational Behavior, 33: 316-341.

Dutton, J. E., \& Heaphy, E. D. 2003. The power of high-quality connections. In K. Cameron, J. E. Dutton, \& R. Quinn (Eds.), Positive organizational scholarship: Foundations of a new discipline: 263-278. San Francisco: Berrett-Koehler.

Deep Help 
Eisenhardt, K. M. 1989. Making fast strategic decisions in high-velocity environments. Academy of Management Journal, 32: 543-576.

Elsbach, K. D., \& Flynn, F. J. 2013. Creative collaboration and the self-concept: A study of toy designers. Journal of Management Studies, 50: 515-544.

Fisher, C. M. 2017. An ounce of prevention or a pound of cure? Two experiments on in-process interventions in decision-making groups. Organizational Behavior and Human Decision Processes, 138: 59-73.

Fisher, C. M., \& Amabile, T. M. 2009. Creativity, improvisation and organizations. In T. Rickards, M. A. Runco, \& S. Moger (Eds.), The Routledge companion to creativity: 13-24. New York: Routledge.

Flanagan, J., C. 1954. The critical incident technique. Psychological Bulletin, 51: 327-327.

Flynn, F. J. 2006. How much is it worth to you? Subjective evaluations of help in organizations. Research in Organizational Behavior, 27: 133-174.

Flynn, F. J., \& Lake, V. K. B. 2008. If you need help, just ask: Underestimating compliance with direct requests for help. Journal of Personality and Social Psychology, 95: 128-143.

Gergen, K. J., \& Gergen, M. M. 1983. The social construction of helping relationships. In J. Fisher, J. D. Fisher, A. Nadler, \& B. M. DePaulo (Eds.), New directions in helping: Recipient reactions to aid, vol. 1: 144-166. New York: Academic Press.

Gioia, D. A., Corley, K. G., \& Hamilton, A. L. 2013. Seeking qualitative rigor in inductive research: Notes on the Gioia Methodology. Organizational Research Methods, 16: 15-31.

Goffman, E. 1967. Interaction ritual: Essays in face to face behavior. New Brunswick, NJ: Transaction Publishers.

Golan, M. E., \& Bamberger, P. A. 2015. Mapping the emergent choreography of assistance: The dynamics of dyadic peer helping relations in organizations. Academy of Management Discoveries, 1: 124-149.

Gouldner, A. W. 1960. The norm of reciprocity: A preliminary statement. American Sociological Review, 25: 161-178.

Graen, G. B., \& Uhl-Bien, M. 1995. Relationship-based approach to leadership: Development of leader-member exchange (LMX) theory of leadership over 25 years: Applying a multi-level multi-domain perspective. The Leadership Quarterly, 6: 219-247.

Grant, A. M., \& Patil, S. V. 2012. Challenging the norm of self-interest: Minority influence and transitions to helping norms in work units. Academy of Management Review, 37: 547-568.

Grodal, S., Nelson, A. J., \& Siino, R. M. 2015. Help-seeking and help-giving as an organizational routine: Continual engagement in innovative work. Academy of Management Journal, 58: 136-168.

Hackman, J. R., \& Wageman, R. 2005. A theory of team coaching. Academy of Management Review, 30: 269-287.

Hargadon, A. B., \& Bechky, B. A. 2006. When collections of creatives become creative collectives: A field study of problem solving at work. Organization Science, 17: 484-500.

Harrison, S. H., \& Rouse, E. D. 2015. An inductive study of feedback interactions over the course of creative projects. Academy of Management Journal, 58: 375-404. 
Hernes, T., Simpson, B., \& Söderlund, J. 2013. Managing and temporality. Scandinavian Journal of Management, 29: 1-6.

Higgins, M. C., \& Kram, K. E. 2001. Reconceptualizing mentoring at work: A developmental network perspective. Academy of Management Review, 26: 264-288.

Hofmann, D. A., Lei, Z., \& Grant, A. M. 2009. Seeking help in the shadow of doubt: The sensemaking processes underlying how nurses decide whom to ask for advice. Journal of Applied Psychology, 94: 1261-1274.

Katz, D., \& Kahn, R. L. 1978. The social psychology of organizations. New York: John Wiley \& Sons.

Kellogg, K. C., Orlikowski, W. J., \& Yates, J. 2006. Life in the trading zone: Structuring coordination across boundaries in postbureaucratic organizations. Organization Science, 17: $22-44$.

Kozlowski, S. W. J., Mak, S., \& Chao, G. T. 2016. Team-centric leadership: An integrative review. Annual Review of Organizational Psychology and Organizational Behavior, 3: 2154.

Langley, A. 1999. Strategies for theorizing from process data. Academy of Management Review, 24: 691-710.

Langley, A., \& Tsoukas, H. (Eds.). 2017. The SAGE Handbook of Process Organization Studies. London: Sage Publications.

Lee, F. 2002. The social costs of seeking help. The Journal of Applied Behavioral Science, 38: $17-35$.

LePine, J. A., Erez, A., \& Johnson, D. E. 2002. The nature and dimensionality of organizational citizenship behavior: A critical review and meta-analysis. Journal of Applied Psychology, 87: 52-65.

Liden, R. C., Wayne, S. J., Liao, C., \& Meuser, J. D. 2014. Servant leadership and serving culture: Influence on individual and unit performance. Academy of Management Journal, 57: 1434-1452.

Locke, K. 2001. Grounded theory in management research. London: Sage Publications.

Long Lingo, E., \& O’Mahony, S. 2010. Nexus work: Brokerage on creative projects. Administrative Science Quarterly, 55: 47-81.

MacKenzie, S. B., Podsakoff, P. M., \& Ahearne, M. 1998. Some possible antecedents and consequences of in-role and extra-role salesperson performance. Journal of Marketing, 62: 87-98.

Manz, C. C., \& Sims Jr., H. P. 1987. Leading workers to lead themselves: The external leadership of self-managing work teams. Administrative Science Quarterly, 32: 106-129.

March, J. G., \& Simon, H. A. 1958. Organizations. New York: Wiley.

March, J. G., \& Olsen, J. P. 2004. The logic of appropriateness. In R. E. Goodin (Ed.), The Oxford handbook of political science: 479-497. Oxford, U.K.: Oxford University Press.

McClelland, D. C. 1998. Identifying competencies with Behavioral-Event Interviews. Psychological Science, 9: 331-339.

Methot, J. R., Lepak, D., Shipp, A. J., \& Boswell, W. R. 2017. Good citizen interrupted: 
Calibrating a temporal theory of citizenship behavior. Academy of Management Review, 42: $10-31$.

Metiu, A., \& Rothbard, N. P. 2013. Task bubbles, artifacts, shared emotion, and mutual focus of attention: A comparative study of the microprocesses of group engagement. Organization Science, 24: 455-475.

Mohammed, S., \& Nadkarni, S. 2011. Temporal diversity and team performance: The moderating role of team temporal leadership. Academy of Management Journal, 54: 489508.

Morgeson, F. P. 2005. The external leadership of self-managing teams: Intervening in the context of novel and disruptive events. Journal of Applied Psychology, 90: 497-508.

Morgeson, F. P., DeRue, D. S., \& Karam, E. P. 2010. Leadership in teams: A functional approach to understanding leadership structures and processes. Journal of Management, 36 : 5-39.

Morrison, E. W. 1994. Role definitions and organizational citizenship behavior: The importance of the employee's perspective. Academy of Management Journal, 37: 1543-1567.

Nadler, A. 1987. Determinants of help seeking behaviour: The effects of helper's similarity, task centrality and recipient's self-esteem. European Journal of Social Psychology, 17: 57-67.

Nadler, A. 2015. The other side of helping: Seeking and receiving help. In D. Schroeder \& W. Graziano (Eds.), Oxford library of psychology. The Oxford handbook of prosocial behavior: 307-328. Oxford, U.K.: Oxford University Press.

Nadler, A., Ellis, S., \& Bar, I. 2003. To seek or not to seek: The relationship between help seeking and job performance evaluations as moderated by task-relevant expertise. Journal of Applied Social Psychology, 33: 91-109.

Nadler, A., \& Halabi, S. 2006. Intergroup helping as status relations: Effects of status stability, identification, and type of help on receptivity to high-status group's help. Journal of Personality and Social Psychology, 91: 97-110.

Perlow, L., \& Weeks, J. 2002. Who's helping whom? Layers of culture and workplace behavior. Journal of Organizational Behavior, 23: 345-361.

Perry-Smith, J. E., \& Mannucci, P. V. 2017. From creativity to innovation: The social network drivers of the four phases of the idea journey. Academy of Management Review, 42: 53-79.

Podsakoff, N. P., Whiting, S. W., Podsakoff, P. M., \& Blume, B. D. 2009. Individual- and organizational-level consequences of organizational citizenship behaviors: A meta-analysis. Journal of Applied Psychology, 94: 122-141.

Rajan, R. G., \& Wulf, J. 2006. The flattening firm: Evidence from panel data on the changing nature of corporate hierarchies. Review of Economics \& Statistics, 88: 759-773.

Rouse, E. (2016). Beginning's end: How founders psychologically disengage from their organizations. Academy of Management Journal, 59, 1605-1629.

Rousseau, D. M. 2004. Psychological contracts in the workplace: Understanding the ties that motivate. Academy of Management Executive, 18: 120-127.

Sutton, R. I., \& Hargadon, A. 1996. Brainstorming groups in context: Effectiveness in a product design firm. Administrative Science Quarterly, 41: 685-718.

Toegel, G., Kilduff, M., \& Anand, N. 2013. Emotion helping by managers: An emergent

Deep Help 
understanding of discrepant role expectations and outcomes. Academy of Management Journal, 56: 334-357.

Von Nordenflycht, A. 2010. What is a professional service firm? Toward a theory and taxonomy of knowledge-intensive firms. Academy of Management Review, 35: 155-174.

Wageman, R. 2001. How leaders foster self-managing team effectiveness: Design choices versus hands-on coaching. Organization Science, 12: 559-577.

Wuchty, S., Jones, B. F., \& Uzzi, B. 2007. The increasing dominance of teams in production of knowledge. Science, 316(5827): 1036-1039.

Zerubavel, E. 1985. Hidden rhythms: Schedules and calendars in social life. Berkeley: University of California Press. 
Table 1. Projects Observed During Round 2 Data Collection, Descriptive Statistics

\begin{tabular}{llllll}
\hline & $\begin{array}{l}\text { Canadian } \\
\text { Health } \\
\text { Works }\end{array}$ & $\begin{array}{l}\text { Pharma } \\
\text { Process }\end{array}$ & $\begin{array}{l}\text { Medical } \\
\text { Device }\end{array}$ & $\begin{array}{l}\text { Auto } \\
\text { Strategy }\end{array}$ & Total \\
\hline Project length (weeks) & 7 & 12 & 6 & 6 & 31 \\
$\quad \begin{array}{l}\text { Project workdays } \\
\text { Diary response rate (\%) }\end{array}$ & 33 & 53 & 30 & 29 & 145 \\
$\quad \begin{array}{l}\text { SMS diary entries } \\
\text { Number of core team }\end{array}$ & 86 & 74 & 100 & 75 & 78 \\
$\quad 2$ & 157 & 81 & 77 & 401 \\
$\quad \begin{array}{l}\text { Numbers } \\
\quad \text { weekly interviews }\end{array}$ & 11 & 4 & 3 & 4 & 13 \\
$\quad \begin{array}{l}\text { Number of help-givers } \\
\text { Number of help-giver }\end{array}$ & 4 & 33 & 16 & 17 & 77 \\
$\quad$ interviews & 11 & 6 & 2 & 2 & 14 \\
$\begin{array}{l}\text { Helpfulness ratings }(N) \\
\text { Help incidents per diary }\end{array}$ & 66 & 6 & 11 & 4 & 32 \\
$\quad$ entry (\%) & 77 & 67 & 42 & 28 & 233 \\
\hline
\end{tabular}


Table 2. Summary of Deep-Helping Cases

\begin{tabular}{lll}
\hline Case & $\begin{array}{l}\text { Informants and } \\
\text { Data Sources } \\
\text { Guiding Cases }\end{array}$ & Case Overview \\
\hline $1 \quad \begin{array}{l}\text { G06 (Project Lead in } \\
\text { whitespace (between } \\
\text { projects) }\end{array}$ & $\begin{array}{l}\text { Very early in the project, the PL asked Hazel (G06) to use her whitespace to spend several consecutive } \\
\text { days with the team during Synthesis. Though Hazel had attended an early brainstorm, she spent the first } \\
\text { day steeping (listening and asking questions). On the second and third days, she suggested a framework } \\
\text { to help the team understand and communicate their key insights, move forward, and articulate ideas. }\end{array}$ \\
\hline \multirow{2}{*}{ R01 (Project Lead) } & $\begin{array}{l}\text { The team, working on a lucrative project, was hobbled by personal issues and disengagement. Aaron } \\
\text { (R01) emailed the client contact, Gary, a partner he knew only slightly, for advice. To his surprise, Gary } \\
\text { offered to fly in to work with the team for three consecutive days the next week. Gary emphasized that he } \\
\text { was there to serve as a "crutch" for Aaron; he advised Aaron to make the project a space in which to } \\
\text { forget about personal problems and to make the project more fun. This strategy was successful; the team } \\
\text { was on track when Gary left at the scheduled time. }\end{array}$ \\
\hline
\end{tabular}

\begin{tabular}{|c|c|c|}
\hline $3 *$ & $\begin{array}{l}\text { Team Canadian Health } \\
\text { Works (Round } 2 \text { data) } \\
\text { G05 (Project Lead in } \\
\text { whitespace) } \\
\text { R06 (Project Lead) } \\
\text { R07 (Team member) }\end{array}$ & $\begin{array}{l}\text { The team was reaching the end of the research phase and anticipating the transition to design. After } \\
\text { briefly interacting with Violet (G05), the team scheduled three 2-hour-long sessions (a total of } 6 \text { hours) } \\
\text { with her in a single day (Day 11). Violet facilitated a process whereby the team combined insights from } \\
\text { research and created a conceptual scheme for the design (see Figure 2). }\end{array}$ \\
\hline 4 & G11 (Design director) & $\begin{array}{l}\text { G11 was asked for help on a project for a frequent Glow client. Because he was familiar with prior work } \\
\text { for the client and worked near the team's space, he had a general awareness of the project. The team } \\
\text { asked for help deciding between two approaches to the design; G11 considered his superficial knowledge } \\
\text { inadequate for a project with such technically complex engineering. He scheduled } 75 \text { minutes on each of } \\
\text { three consecutive days. The first day he mapped the project, asking questions and listening to the team's } \\
\text { ideas. The next two days he was more active but viewed the team as the intellectual leaders, who would } \\
\text { "take my stupid question and twist it around to something that made sense, and discuss that for a while." } \\
\text { Ultimately he helped the team refine and feel confident about its choice of direction. }\end{array}$ \\
\hline $5^{*}$ & $\begin{array}{l}\text { Team Pharma Process } \\
\text { (Round } 2 \text { data) } \\
\text { G04 (Area lead) } \\
\text { R03 (Project Lead) } \\
\text { R15 (Team member) } \\
\text { R09 (Team member) } \\
\end{array}$ & $\begin{array}{l}\text { Ron (G04) was part of a leadership group that had been approached about the team's staffing problem } \\
\text { (Days 23, 45) but was initially to busy to help much. After a talk with the PL, he concluded that the } \\
\text { technical part of the project needed "a little bit of reinforced direction." In Phase } 2 \text { he took it on himself } \\
\text { to work intensely with the team on } 4 \text { consecutive days (Days } 49,50,51,52 \text { ) conceptualizing the website } \\
\text { they were working on; he mapped the situation by "asking some really good probing questions" (R09) for } \\
\text { an hour, and then "got his hands dirty" (R15) showing them ways to visualize their ideas (see Figure 2). }\end{array}$ \\
\hline 6 & G04 (Area lead) & $\begin{array}{l}\text { Ron (G04) received a call from a leader at an office three hours away, telling him that a departing team } \\
\text { member was leaving a project without someone experienced in his function. He scheduled one day a } \\
\text { week for several weeks to work at the other office. Observing the project space for the first time, he } \\
\text { worried that the team lacked enough content to begin the design phase. He introduced exercises to } \\
\text { generate content, facilitating the team's ideas rather than contributing his own (to prevent the team from } \\
\text { becoming dependent on him). He canceled his last visit, convinced that the team no longer needed him. }\end{array}$ \\
\hline 7 & G09 (Partner) & $\begin{array}{l}\text { Bill (G09) offered to help with a project that interested him at the start of its research phase. As a partner, } \\
\text { he knew team members and was aware of the client's specifications. He wanted to try an "experiment" } \\
\text { with the Glow process: his aim was to prevent problems he had observed on similar projects by injecting } \\
\text { consideration of the client's brand earlier in the process. Worried that the team would perceive him as a } \\
\text { boss rather than a helper, he worked in concert with other helpers. Early on, he helped the team develop a } \\
\text { process for communicating with the client that took the brand into account. He then removed himself but } \\
\text { occasionally looked in on the project space. The client appreciated the new process and the project was } \\
\text { viewed as a resounding success, but the new process was not institutionalized. }\end{array}$ \\
\hline $8^{*}$ & $\begin{array}{l}\text { Team Medical Device } \\
\text { (Round } 2 \text { data) } \\
\text { G05 (Project Lead for a } \\
\text { different project) } \\
\text { R10 (Project Lead) } \\
\text { R11 (Team member) }\end{array}$ & $\begin{array}{l}\text { Violet (G05) had been mentoring R11, who was new to Glow. Though on vacation during much of this } \\
\text { project, Violet advised the PL, R10, on leading the project (Day } 1 \text { ) and worked with the team to frame its } \\
\text { work on Day } 2 \text {. She helped with synthesis in } 2.5 \text { - and 3-hour meetings on consecutive days, a } \\
\text { contribution that was seen as extremely helpful by the end of Day } 14 \text {; she followed up on Day } 17 \text {, and } \\
\text { provided brief feedback before the client presentation on Days } 29 \text { and } 30 \text {. This was one of the few cases } \\
\text { in which a deep helper was simultaneously working on another project (see Figure } 2 \text { ). }\end{array}$ \\
\hline $9 *$ & $\begin{array}{l}\text { Team Auto Strategy } \\
\text { (Round } 2 \text { data) } \\
\text { G12 (Design director) } \\
\text { R12 (Project Lead) } \\
\text { R14 (Team member) } \\
\text { R15 (Team member) } \\
\text { R16 (Team member) }\end{array}$ & $\begin{array}{l}\text { G12 spent a lot of time on Days } 8-10 \text { helping the team finish research and begin generating ideas; the } \\
\text { team found this extremely helpful. He later gave feedback to the team (Day 20) and participated in a } \\
\text { brainstorming session (Day 21). On Day } 25 \text { he attended the client presentation and helped with logistics. } \\
\text { He sat in on the client call the following day (see Figure 2). }\end{array}$ \\
\hline
\end{tabular}


The team, relatively experienced but full of what the giver, Linda (G02), called "hubris," was approaching the transition from research to design (Synthesis). She was highly familiar with the project, having helped the PL, spoken with other advisors, and stopped by the project space. Worried that

$10 \quad$ G02 (Area lead) information collected by two members seemed unusually "orthogonal," Linda offered to help the team synthesize its information. Our interview focused on the final meeting, at which she asked provocative questions to draw attention to overlap in the research of multiple members. Team members then began to create a framework to synthesize their findings. Linda noted that the process then began to "feel fun," and that the team asked her to leave when they no longer needed help.

Linda (G02), having observed and interacted with the team, worried about its staffing and offered to help; the team ignored the offer. Eventually another giver, who was leaving Glow, asked her to keep an eye on the team. During a chance encounter the PL, feeling overwhelmed and abandoned by other helpers,

$11 \quad$ G02 (Area lead) pleaded for her help. She scheduled three long sessions with the team the next week to work on content; she introduced exercises to generate a clearer conceptual framework. However, she left feeling that the team had improved less than she'd hoped, and its members used little of what was generated in those sessions.

Both G12 and G09 described a case in which G09 helped a team in crisis. About three months into a four-month project, G12 received a complaint from the client; both G12 and G09 had already heard G09 (Partner) "buzz" that the team was struggling and the client was dissatisfied with the PL. After G12 appointed
G13 (Partner) new PL, G09 mapped the project terrain by looking at the work (which was fairly well developed), G13 (Partner) $\quad$ listening, and asking questions. He then led the team through "some methodologies we had developed in some other projects." Although the client was ultimately very happy, G09 felt he hadn't fully succeeded at helping the team insert more "brand values" into the design.

A team member felt that the PL was preventing her from contributing to the project fully by failing to trust her with meaningful tasks. The team member approached a different Area Lead, who suggested to

$13 \quad$ G14 (Area lead) G14 that he offer to help. G14 scheduled three meetings: one with the team member and the other Area Lead, a second with the PL and the disgruntled team member, and a third with the entire team. Both the $\mathrm{PL}$ and the team member were more satisfied with the project after this interaction.

\begin{tabular}{ll}
\hline & $\begin{array}{l}\text { Team Pharma Process } \\
\text { (Round 2 data) }\end{array}$ \\
$14 \quad$ & R03 (Project Lead) \\
G08 (Path-clearer who \\
connected the team with \\
G15)
\end{tabular}

G15 was Glow's area lead for healthcare and a respected senior designer at another office. He had helped the client conceive of the project but had had no further involvement. When Wayne (G08) asked him to help, he contributed modestly to planning synthesis on Days 13 and 17, worked with Violet (R03) in tightly clustered interactions (Days $32,33,35$ ) to refine the conceptual approach to the design, and gave feedback on the final design (Day 37).

Takeover. The giver, Richard, was the client contact. This interaction took place near the end of the project, shortly after Richard returned from vacation. A respected designer, he had provided brief advice throughout the project, attended client calls, and kept abreast of the project. The client had been

$15 \quad$ R02 (Project Lead) somewhat unhappy with early drafts, but the PL, Carole (R02), considered the project largely back on track. She asked Richard for feedback on a pitch to the client that she had already vetted with other senior designers and discussed with the client. After listening to the team's pitch, Richard returned to the project space with Carole and reworked it himself. He then took over the client presentation. The project was quite successful but Carole viewed the episode as among the most negative in her career.

Takeover. Ed (G16) was asked by both the PL and the client to help a team after a difficult presentation. He had led a previous project for the same client and, uneasy about this team's initial staffing, he had joined early brainstorms and client calls. It was soon clear that the team was having trouble

G16 (Project Lead in
whitespace communicating with the client; Ed flew in to work with the team. After participating in a workshop that a team member was leading for the client, he began leading brainstorms and processes, "forcing people to come out of their shells." He worried, though, that the PL "feels like he's losing the reins a bit [and] people are stepping in and taking over for him rather than just helping him. ... It doesn't feel like help anymore. We walk back and forth over this line of who has the reins, and I want the Project Lead to have the reins."

\section{Path-Clearing Cases}

Wayne's (G08) involvement with Team Pharma Process is described in the section on path-clearing in the Findings. In addition to his initial advice about leading the team and his offer to help in the future

Team Pharma Process (Round 2 data) (Days 2, 4), he attended the design review (Day 6) and a workshop (Day 7) with other givers. When the team lost its second member on Day 12, Violet (R03), the PL, asked for help planning Phase 2 (Days 21,

G08 (Client contact) R03 (Project Lead) $24,36,38,40,44,51,53)$. Before beginning that task, he performed the menial task of sketching on Day 15. He also sat in on a client presentation (Day 39) and provided emotional support after a difficult meeting (Day 23). He also connected the team with two other deep helpers (Day 15). His involvement in managing a chaotic and difficult project was perceived as extremely helpful (see Figure 2).

$\begin{array}{ll} & \\ & \begin{array}{l}\text { Team Pharma Process } \\ \text { (Round 2 data) }\end{array} \\ & \text { G10 (Client contact at a } \\ \text { different office) } & \text { R03 (Project Lead) } \\ \text { R07 (Team member) } & \text { R09 (Team member) }\end{array}$

Amelia (G10) was among the most involved givers in our study, helping the team on at least 15 occasions. During staffing, she offered to help the PL manage this unusual project. She attended a design review on Day 6 and, with 4 other non-team members, facilitated an all-day workshop for the client on Day 7. She helped plan the team's research on Days 9 and 11 and began organizing research interviews and site visits after Day 12, when the team became severely understaffed (Days 14, 15, 18). She also helped communicate with the client and attended meetings on the team's behalf (Days 16, 21, 27). She reassured them after a difficult client call (Day 30), reviewed content (Day 37), and helped price and plan Phase 2 (Day 38). She was less involved in Phase 2. 


\begin{tabular}{|c|c|c|}
\hline $19 *$ & $\begin{array}{l}\text { G03 (Area lead) } \\
\text { R06 (Project Lead) } \\
\text { R07 (Team member) }\end{array}$ & $\begin{array}{l}\text { Brad (G03) helped in a range of ways throughout the project, including driving the team to a research site } \\
\text { (Day 1), conducting research (Day 5), giving feedback (Days } 7 \text { and 17), and recruiting additional help } \\
\text { (Day 17). No single episode was rated extremely highly, but the team saw his involvement as critical (see } \\
\text { Figure 2). }\end{array}$ \\
\hline 20 & $\begin{array}{l}\text { Team Pharma Process } \\
\text { (Round } 2 \text { data) } \\
\text { G17 (Senior designer) } \\
\text { R03 (Project Lead) } \\
\text { R07 (Team member) }\end{array}$ & $\begin{array}{l}\text { Tony (G17) became involved with Team Pharma Process after Wayne (G08) asked him to help the team. } \\
\text { A technology expert, he helped fill the void left by a member's health crisis. He generated ideas for } \\
\text { technologies to leverage and summarized information for the team (Days 15, 18, 19,21). Without being } \\
\text { asked, he took the initiative to liaise with the client's technology experts (Days 22, 32). He also took part } \\
\text { in planning Phase } 2 \text { (Day 38) and the client presentation (Day 39). }\end{array}$ \\
\hline 21 & $\begin{array}{l}\text { Team Canadian Health } \\
\text { Works (Round } 2 \text { data) } \\
\text { G18 (Functional expert) } \\
\text { R06 (Project Lead) } \\
\text { R07 (Team member) }\end{array}$ & $\begin{array}{l}\text { G18 offered expertise on engineering and technology, as well as personal familiarity with the health } \\
\text { problem central to the client's mission. He performed a "tech audit" for the team (Days 2,3), prepared } \\
\text { information for the client (Day 9), and helped plan a brainstorm (Day 22). }\end{array}$ \\
\hline 22 & $\begin{array}{l}\text { Team Canadian Health } \\
\text { Works (Round } 2 \text { data) } \\
\text { G19 (Client contact at a } \\
\text { different office) } \\
\text { R06 (Project Lead) } \\
\text { R07 (Team member) }\end{array}$ & $\begin{array}{l}\text { G19 offered advice on dealing with the client (Day } 3 \text { ) and sat in on two client meetings (Days } 7,19 \text { ). His } \\
\text { involvement was seen as only marginally helpful, with characteristics of a check-up; he was rated lowest } \\
\text { among the repeat helpers on this project (see Figure 2). }\end{array}$ \\
\hline $23 *$ & $\begin{array}{l}\text { Team Auto Strategy } \\
\text { (Round } 2 \text { data) } \\
\text { G20 (Project Lead for a } \\
\text { different project) } \\
\text { R12 (Project Lead) }\end{array}$ & $\begin{array}{l}\text { G20 was the PL on one of two similar projects for different divisions of the same multinational company; } \\
\text { his project had begun first and was thus more developed. Busy with his own project, he was slow to } \\
\text { respond to requests for help. But he was seen as very helpful in sharing information over the phone (Day } \\
\text { 11) and participating in conference calls with the client (Days 17, 20) (see Figure 2). }\end{array}$ \\
\hline 24 & $\begin{array}{l}\text { Team Pharma Process } \\
\text { (Round } 2 \text { data) } \\
\text { G21 (Senior designer) } \\
\text { G08 (Client contact) } \\
\text { R03 (Project Lead) } \\
\text { R07 (Team member) }\end{array}$ & $\begin{array}{l}\text { In Team Pharma Process, G21 was a designer who participated in a group design review (Day 6) and a } \\
\text { group brainstorm (Day 7) and gave feedback on a design (Day 15). }\end{array}$ \\
\hline $25^{*}$ & $\begin{array}{l}\text { Team Medical Device } \\
\text { (Round } 2 \text { data) } \\
\text { G04 (Area lead) } \\
\text { R10 (Project Lead) } \\
\text { R05 (Team member) }\end{array}$ & $\begin{array}{l}\text { Ron's (G04) help had elements of swoop-and-poop. He kept in touch with the project because } 2 \text { of the } 3 \\
\text { team members were new to Glow, and the more experienced PL was still finishing another project } \\
\text { (unusual at Glow). Early on he tried to provide advice and feedback (Days } 2,5,6 \text { ) but the project was } \\
\text { highly technical and much of his time was spent trying to understand it. He was more helpful planning } \\
\text { the research phase (Day 7) and planning a brainstorming session (Day 8). But he was seen as disruptive } \\
\text { during a meeting on Day 16, which a member described as "confusing" (R05). He stopped by to offer } \\
\text { feedback and reassurance toward the end of the project (Days } 26,27,29) \text { (see Figure 2). }\end{array}$ \\
\hline 26 & R08 (Project Lead) & $\begin{array}{l}\text { Swoop-and-Poop. In the middle of a 13-week project, Roger (R08), the PL, and a team member were } \\
\text { working on documents to be submitted to the client. The giver, a client contact, offered to edit the } \\
\text { documents. Her help was regarded as a swoop-and-poop; as she constantly offered "editorial comments } \\
\text { without suggestions." After a couple of weeks, she "got the message" that her help was viewed as } \\
\text { unhelpful. }\end{array}$ \\
\hline 27 & R04 (Team member) & $\begin{array}{l}\text { Swoop-and-Poop. R04 described almost daily drop-ins from help-givers during a brief (three weeks) but } \\
\text { interesting project. "Rather than being a single incident, this was a repetitive pattern. . . It was a } \\
\text { hindrance rather than a help, because you just get the wrong information at the wrong time and the } \\
\text { rhythm gets off." The givers "just kept drifting in, [and] would suggest things that we had already } \\
\text { processed and moved on from." The result was a "snowball of input." }\end{array}$ \\
\hline
\end{tabular}

${ }^{*}$ Cases marked with asterisks are depicted in Figure 2.

Note: At Glow, being between projects is known as being "in whitespace." Cases drawn from Round 2 data collection (daily diaries/weekly interviews) are identified in the Informants and Data Sources column. Other cases are drawn from Round 3 data collection (critical-incident interviews).

Cases are sequenced by the strength of the evidence for fit with the theoretical model (Figure 3), from strongest to weakest, within Guiding Cases and Path-Clearing Cases respectively. The final two Guiding cases, 15 and 16, represent the deviations from the guiding process that we call takeovers. The final two Path-Clearing cases, 26 and 27, represent the deviations from the path-clearing process that we call swoop-and-poops. 


\section{Table 3. Key Concepts in Surveying}

\begin{tabular}{|c|c|c|}
\hline Phase & Concept & Representative Examples \\
\hline \multirow{10}{*}{ Surveying } & \multirow{2}{*}{ Prior knowledge } & $\begin{array}{l}\text { "I was one of the people who kind of got the project off the ground and helped staff it" (Linda, } \\
\text { C10-G02). }\end{array}$ \\
\hline & & $\begin{array}{l}\text { "This is Anna's (R06) first experience as a Project Lead, so I'm trying to help her with things she } \\
\text { needs to do . . both internally and with the client" (Brad, C19-G03; also see Figure 2). }\end{array}$ \\
\hline & \multirow{3}{*}{$\begin{array}{l}\text { Observing } \\
\text { artifacts }\end{array}$} & $\begin{array}{l}\text { "I walked in [to the project space] and I said, 'Wow, that's a lot of information,' and I'm thinking, } \\
\text { 'I know they're not ready for synthesis"' (Linda, C10-G02). }\end{array}$ \\
\hline & & $\begin{array}{l}\text { "I would just kind of look at the document [to see] if I saw something that I thought that I could } \\
\text { help with or push the work" (C9-G12) (see Figure 2, Day 8). }\end{array}$ \\
\hline & & $\begin{array}{l}\text { "Their project space is alive. ... You have all your photos, research, your inspiration, that would } \\
\text { be on the walls ... And those are torn down one day, the whole room just changes the next day, so } \\
\text { it's very active, very active space" (Bill, C7-G09). }\end{array}$ \\
\hline & & "I e-mailed him and said, 'Can you come by on your first day back?"” (Carole, C15-R02). \\
\hline & Receiver requests & $\begin{array}{l}\text { "I had had a conversation with [the PL] where she was concerned about the strategic level of her } \\
\text { team ... moving from insight to strategy. She wanted someone that could come in and help bring } \\
\text { the team along" (Hazel, C1-G06). }\end{array}$ \\
\hline & \multirow{3}{*}{$\begin{array}{l}\text { Receiver distress } \\
\text { amplifying issues }\end{array}$} & $\begin{array}{l}\text { The giver "first asked me how I was feeling, not even what the situation was. And [I said], 'It's } \\
\text { frustrating, because I have the best team, this is an amazing project, and yet here we are not } \\
\text { engaged with the project. And I don't know how to change the dynamics . . . so I am frustrated"" } \\
\text { (Aaron, C2-R01). }\end{array}$ \\
\hline & & $\begin{array}{l}\text { The PL "basically was having a breakdown in his personal life. And the team was completely } \\
\text { floundering, and there wasn't a lot of progress being made, and everybody kind of knew it" (Ron, } \\
\text { C6-G04). }\end{array}$ \\
\hline & & $\begin{array}{l}\text { "The team was struggling because they were really in a rut, doing things the old way, and it wasn't } \\
\text { leading to a successful outcome. And it turned into such a meltdown, between inability to deliver } \\
\text { on that and personality conflict, that we ended up having to . . switch off the Project Leaders. And } \\
\text { at one point we're offering a return of fees because it was such a meltdown" (Bill, C12-G09). }\end{array}$ \\
\hline
\end{tabular}

Note: Informants are identified as givers $(\mathrm{G})$ or receivers $(\mathrm{R})$ of help and assigned unique identifying numbers based on the sequence in which they are introduced in the manuscript. Quotations are identified by the case numbers provided in Table 2. For instance, C19-G03 signifies Case 19, Giver 03 . 
Table 4. Key Concepts in Guiding

\begin{tabular}{|c|c|c|}
\hline Phase & Concept & Representative Examples \\
\hline \multirow{2}{*}{$\begin{array}{l}\text { Identifying the } \\
\text { Issue }\end{array}$} & \multirow{2}{*}{ Critical juncture } & $\begin{array}{l}\text { "[G12] came in at a critical moment and helped go through each [option for proceeding]" (C9-R14) } \\
\text { (see Figure 2, C9-G12). }\end{array}$ \\
\hline & & $\begin{array}{l}\text { "It was kind of past the midpoint, so they had done [field research]. After they'd had a big workshop } \\
\text { [presenting to the client], it was just really clear that they just knew too much" (Linda, C10-G02). }\end{array}$ \\
\hline \multirow{3}{*}{$\begin{array}{l}\text { Adopting a } \\
\text { rhythm }\end{array}$} & \multirow{3}{*}{$\begin{array}{l}\text { Giver and } \\
\text { receiver schedule } \\
\text { long, tightly } \\
\text { clustered } \\
\text { interactions }\end{array}$} & $\begin{array}{l}\text { The giver offered to fly from the West Coast to the East Coast to help the team, telling R01, "I will } \\
\text { come to New York just to spend that week with you guys" (Aaron, C2-R01). }\end{array}$ \\
\hline & & $\begin{array}{l}\text { After the PL made an agitated request for help, "We scheduled a bunch of these good three-hour } \\
\text { work sessions pretty much right away" (Linda, C11-G02). }\end{array}$ \\
\hline & & "We tried to schedule it. We set up a block of time" (Anna, C3-R06) (see Figure 2, C3-G05). \\
\hline \multirow{3}{*}{$\begin{array}{l}\text { Establishing } \\
\text { the helping } \\
\text { frame }\end{array}$} & \multirow{3}{*}{$\begin{array}{l}\text { Giver makes a } \\
\text { specific offer to } \\
\text { help and clarifies } \\
\text { role }\end{array}$} & $\begin{array}{l}\text { "I can take off of your plate some of the pressure of the project work. So I'm going to be your crutch" } \\
\text { (Aaron, C2-R01). }\end{array}$ \\
\hline & & $\begin{array}{l}\text { "My focus was around the team doing well and developing good work" (Violet, C8-G05) (see Figure } \\
\text { 2). }\end{array}$ \\
\hline & & $\begin{array}{l}\text { "In my role, I was not supposed to do anything. I was supposed to be there to help-help them think } \\
\text { about how they're going to go about doing their work" (Bill, C7-G09). }\end{array}$ \\
\hline \multirow{3}{*}{ Mapping } & \multirow{3}{*}{$\begin{array}{l}\text { Giver steeps in } \\
\text { the project }\end{array}$} & $\begin{array}{l}\text { "It was my first time coming in, so I was just trying to get up to speed. I knew a little bit about the } \\
\text { project, but not that much. And so I sat with [the receivers] for about an hour. ... Most of what I did } \\
\text { was actually ask why they were designing those pieces, and what the purpose was for each of them" } \\
\text { (Ron, C5-G04) (See Figure 2, Day 49). }\end{array}$ \\
\hline & & $\begin{array}{l}\text { "The first day I was really just taking it in. The first part of the second day, I was really still just } \\
\text { letting them tell me. And then, by the second half of the second day, and by the third day, I was } \\
\text { starting to start leading some thinking" (Hazel, C1-G06). }\end{array}$ \\
\hline & & $\begin{array}{l}\text { "The way I go about it is asking them to go ahead and just start talking to me about what they've } \\
\text { done and why they've made the decisions they have.... So we sit down and we start going through } \\
\text { the wall and start looking at designs, talking about what theme they're trying to present" (Bill, C12- } \\
\text { G09). }\end{array}$ \\
\hline \multirow{2}{*}{$\begin{array}{l}\text { Reinforcing the } \\
\text { helping frame }\end{array}$} & \multirow{2}{*}{$\begin{array}{l}\text { Giver and } \\
\text { receivers convey } \\
\text { mutual } \\
\text { understanding }\end{array}$} & $\begin{array}{l}\text { "Very sharp guys, you know-they'd take my stupid question and twist it around to something that } \\
\text { maybe made sense, and discuss that for a while" (C4-G11). }\end{array}$ \\
\hline & & $\begin{array}{l}\text { "I'm almost just trying to find some of the richness of their content that they aren't exactly talking } \\
\text { about, but it's definitely there." (C9-G12) (see Figure 2) }\end{array}$ \\
\hline \multirow{3}{*}{ Ranging } & \multirow{3}{*}{$\begin{array}{l}\text { Giver introduces } \\
\text { a new work } \\
\text { process }\end{array}$} & $\begin{array}{l}\text { "One of the most inspirational moments was when we spent the day filling the entire wall with } \\
\text { drawings that would help inspire conversation. ... [The receiver] would make collages from his } \\
\text { sketchbook and then photocopy that and scan it and send it that way. The client really appreciated it } \\
\text { because they thought, "Wow, they're really getting into our work" (Bill, C7-G09). }\end{array}$ \\
\hline & & $\begin{array}{l}\text { "They were in a state of swirl, of knowing a lot. And I just started saying-I said, 'Well, first, let's } \\
\text { start off with ... if they would design as many devices as you possibly want, what's the maximum } \\
\text { number of devices?' ... And so then we had that all mapped out, and just, like, through mapping out } \\
\text { what would be your ideal, just helping them synthesize on the fly how they'd solve those problems. } \\
\text { And then at the end of it... they all said it started to have a roadmap, because they knew what these } \\
\text { two cases were, and they knew what some acceptable cases in the middle were" (Linda, C10-G02). }\end{array}$ \\
\hline & & $\begin{array}{l}\text { "Violet teaches the process as well, so she is really good at getting teams who are drowning in a lot of } \\
\text { content and then really quickly and efficiently helping them" (Anna, C3-R06) (see Figure 2, C3- } \\
\text { G05). }\end{array}$ \\
\hline Ending & $\begin{array}{l}\text { Giver withdraws } \\
\text { when the allotted } \\
\text { time ends or } \\
\text { receivers reassert } \\
\text { autonomy }\end{array}$ & $\begin{array}{l}\text { "Violet [G05] stopped in for three separate sessions today, each for roughly } 2 \text { hours.... Yesterday } \\
\text { was a frustrating moment in the project, and we identified approaches toward moving forward. } \\
\text { Today those things happened and now we're in a much more generative space. We did accomplish all } \\
\text { the goals that we had set forth and [are] feeling good about the work now" (Anna, C3-R06) (see } \\
\text { Figure 2, Day 11, C3-G05). }\end{array}$ \\
\hline $\begin{array}{l}\text { Process } \\
\text { deviations }\end{array}$ & Takeovers & $\begin{array}{l}\text { "How do we switch gears on the core team? How do we get them in a new way of thinking? That's } \\
\text { where I'm sort of leading, and this is where the project lead starts to get frustrated. He feels like he's } \\
\text { losing the reins a bit-feels like people are stepping in and taking over for him rather than just } \\
\text { helping him. ... I'm not just helping him present anymore. I'm actually taking over a little bit to help } \\
\text { him get the project back on the rails. . . There was one day where he was visibly frustrated and not } \\
\text { happy. And that worried me, that he felt like he wasn't being valued, that what he was doing was just } \\
\text { fucking things up more, when in fact he was contributing. It just didn't feel that way" (C16-G16). }\end{array}$ \\
\hline
\end{tabular}

Note: Informants are identified as givers (G) or receivers (R) of help and assigned unique identifying numbers based on the sequence in which they are introduced in the manuscript. Quotations are identified by the case numbers provided in Table 2. For instance, C19-G03 signifies Case 19, Giver 03. 
Table 5. Key Concepts in Path-Clearing

\begin{tabular}{|c|c|c|}
\hline Phase & Concept & Representative Examples \\
\hline \multirow{2}{*}{$\begin{array}{l}\text { Identifying the } \\
\text { issue }\end{array}$} & \multirow{2}{*}{$\begin{array}{l}\text { Persistent } \\
\text { deficiency }\end{array}$} & $\begin{array}{l}\text { "It was my second project at Glow, so I was still fairly new here. And I wanted, on this project, to really } \\
\text { try to take in as much as I could about how things are done here" (Sean, C27-R04). }\end{array}$ \\
\hline & & $\begin{array}{l}\text { "It's a fuzzy project that the outcome could be any of an infinite number of potential business } \\
\text { opportunities so it's difficult to judge progress" (C21-G18). }\end{array}$ \\
\hline \multirow{4}{*}{$\begin{array}{l}\text { Establishing the } \\
\text { helping frame }\end{array}$} & \multirow{2}{*}{$\begin{array}{l}\text { Giver makes } \\
\text { generalized } \\
\text { offer to help } \\
\text { and waits }\end{array}$} & $\begin{array}{l}\text { "I'm supporting the team. ... I want to make sure that they get what they were looking for. . . } \\
\text { Whenever they've needed help, I think they've reached out" (C22-G19). }\end{array}$ \\
\hline & & $\begin{array}{l}\text { "[The giver] sounds like he's very interested in staying connected more broadly, which-I have to be } \\
\text { honest-it's like a totally pleasant surprise to me, because I just thought nobody cared about this project } \\
\text { at all... . But he was open to it, and I thought that was pretty cool" (Violet, C20-R03). }\end{array}$ \\
\hline & \multirow{2}{*}{$\begin{array}{l}\text { Receiver } \\
\text { makes an } \\
\text { initial specific } \\
\text { request }\end{array}$} & $\begin{array}{l}\text { "Being new to the HF [Human Factors] way, I really didn't know how I could contribute [to the research } \\
\text { stage of the project] ... I e-mailed Ron (G04) and he's like, 'Hey, we can jump on the phone at 3:00"” } \\
\text { (Craig, C25-R05) (see Figure 2, C25-G04). }\end{array}$ \\
\hline & & $\begin{array}{l}\text { "I called G19 because we're having a lot of trouble scheduling a workshop with the client" (Anna, C22- } \\
\text { R06). }\end{array}$ \\
\hline \multirow{2}{*}{$\begin{array}{l}\text { Adopting a } \\
\text { rhythm }\end{array}$} & \multirow{2}{*}{$\begin{array}{l}\text { Short, } \\
\text { scattered } \\
\text { interactions }\end{array}$} & $\begin{array}{l}\text { Amelia (C18-G10) helped Team Pharma Process on Days 6, 9, 11, 14, 16, 17, 19, 21, 24, 27, 30, 37, and } \\
38 \text {. }\end{array}$ \\
\hline & & $\begin{array}{l}\text { Brad (C19-G03) helped Team Canadian Health Works on Days 1, 2, 4, 5, 6, 7, 15, 17, 18, and 22; the } \\
\text { episodes lasted 5-90 minutes (see Figure 2). }\end{array}$ \\
\hline \multirow[t]{2}{*}{ Mapping } & \multirow[t]{2}{*}{$\begin{array}{l}\text { Giver looks } \\
\text { ahead }\end{array}$} & $\begin{array}{l}\text { "I talked with G15 today. ... Violet needs support from others that I'm not able to give. So we're } \\
\text { creating a little bit more of an advisorship or coaching [resource], because sometimes you need to just be } \\
\text { running things by people all the time so that they can spot 'Oh, I'm a little worried about the way you } \\
\text { said that"" (C17-G08) (see Figure 2, Day 15). }\end{array}$ \\
\hline & & $\begin{array}{l}\text { "It's me helping the team making the contact, and resolve that issue that was a client request. ... I think } \\
\text { it was helpful. The team didn't ask me to do that. I volunteered that" (Brad, C19-G03) (see Figure 2). }\end{array}$ \\
\hline \multirow[b]{2}{*}{ Ranging } & \multirow[b]{2}{*}{$\begin{array}{l}\text { Giver fills a } \\
\text { hole }\end{array}$} & $\begin{array}{l}\text { "Ron (G04) just popped in and helped identify things we aren't explaining clearly and reshuffle where } \\
\text { we wanted to spend time. He's getting more and more familiar, so he can jump in and see progress rather } \\
\text { than getting caught up on [the] project" (C25-R07) (see Figure 2, C25-G04). }\end{array}$ \\
\hline & & $\begin{array}{l}\text { "I realized I could not hold up the planning [of] the next-phase part of this project while I'm trying to } \\
\text { finish this phase. So I asked him to step in and do that. And so this is now a continuous thing that he's } \\
\text { been doing. . . And he joined on the client call as well, that we had on Monday, just to be backup on } \\
\text { those kinds of questions" (Brad, C17-R03) (see Figure 2, Day 5, C17-G08). }\end{array}$ \\
\hline \multirow[b]{2}{*}{$\begin{array}{l}\text { Reinforcing the } \\
\text { helping frame }\end{array}$} & \multirow{2}{*}{$\begin{array}{l}\text { Giver conveys } \\
\text { availability } \\
\text { and/or } \\
\text { performs } \\
\text { menial tasks }\end{array}$} & $\begin{array}{l}\text { "Brad (G03) helped us sketch on Wednesday.... It was a really generic sketch. There wasn't a whole lot } \\
\text { of thinking behind it; it was just more of a placeholder" (C19-R15) (see Figure 2, C19-G03). }\end{array}$ \\
\hline & & $\begin{array}{l}\text { "G21 went on a [research] interview with me and took notes. It was helpful because we came back and } \\
\text { he said, 'I have these notes, what should I do with them?' ... I said: 'If you can just start filling in these } \\
\text { buckets of information for that interview that you were on, that would really help me"” (Anna, C21- } \\
\text { R06). }\end{array}$ \\
\hline \multirow[b]{2}{*}{ Ending } & \multirow{2}{*}{$\begin{array}{l}\text { Giver helps } \\
\text { until the end of } \\
\text { the phase or } \\
\text { the project, as } \\
\text { available }\end{array}$} & $\begin{array}{l}\text { Wayne (C17-G08) served as a path-clearer throughout every phase of the project, from nearly beginning } \\
\text { to end (see Figure 2). }\end{array}$ \\
\hline & & $\begin{array}{l}\text { Ron (C25-G04) served as a path-clearer throughout the project. Although his involvement was heaviest } \\
\text { early in the project, he stuck around when needed throughout (see Figure 2). }\end{array}$ \\
\hline \multirow{2}{*}{$\begin{array}{l}\text { Process } \\
\text { deviations }\end{array}$} & \multirow{2}{*}{$\begin{array}{l}\text { Swoop-and- } \\
\text { poop }\end{array}$} & $\begin{array}{l}\text { "These young project teams don't even feel like they have enough access to [senior designers'] time. } \\
\text { What ends up happening is a senior person will come in and do a 'swoop-and-poop.' [The giver will] } \\
\text { swoop in and poop on my project, and then [the receiver thinks], 'Oh, my god, what am I going to do } \\
\text { now?'” (G15). }\end{array}$ \\
\hline & & $\begin{array}{l}\text { "Someone whipped out a whole bunch of designs for a client, and then the industrial-design director } \\
\text { came in and basically pooped on them. [Industrial design] people sometimes feel like they have a little } \\
\text { bit of "Well, my design is better because I have more experience"" (Violet, R03). }\end{array}$ \\
\hline
\end{tabular}

Note: Informants are identified as givers (G) or receivers (R) of help and assigned unique identifying numbers based on the sequence in which they are introduced in the manuscript. Quotations are identified by the case numbers provided in Table 2. For instance, C19-G03 signifies Case 19, Giver 03. 
Figure 1: Data Collection and Analysis Process

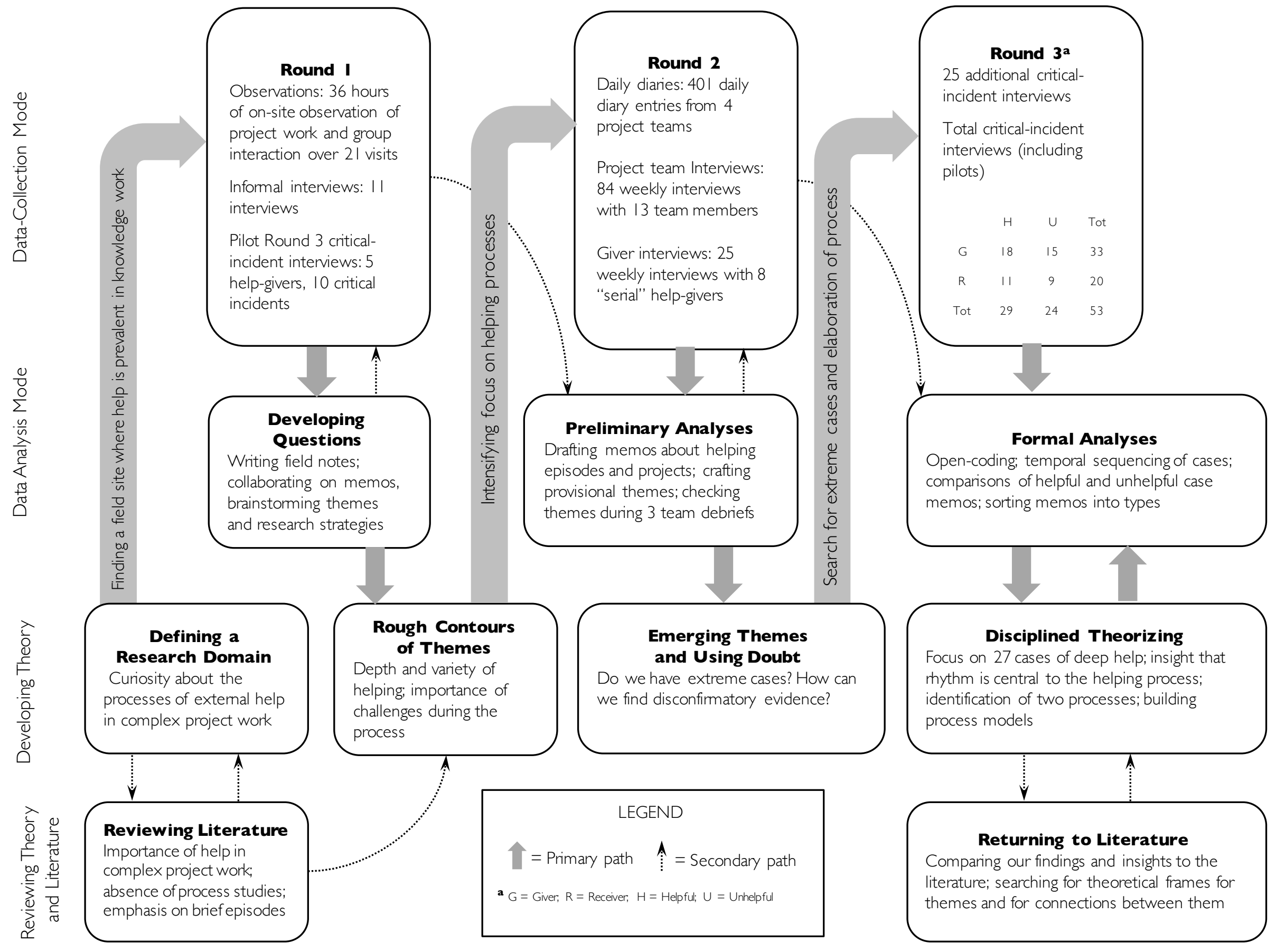


Figure 2: The Two Rhythms of Deep Help as Manifested in Four GlowDesign Projects

PROJECT

Canadian Health Works was

a 2-member team working to craft a new strategy for a nonprofit organization. The client was unusually vague about what it

hoped to achieve. The PL was also

inexperienced in that role.

Team Medical Devices was a 3 -

member team creating a computer console and software platform to assist doctors during surgery. The PL, though

experienced, was also working on another project. The other two members were new to Glow.

Team Auto Strategy was a 4-member team developing a long-term strategy for regional dealers of a major auto company. Complicating matters, another Glow team was working on a similar project for the same client's dealers in a different region.

Team Pharma Process began as a 5 person team designing a clinical testing process for a pharmaceutical company. The project was long and complex. Compounding its issues, the project unexpectedly lost 2 team members.

GUIDING

PATH-CLEARING

Characteristic rhythm: Several prolonged interactions clustered closely together in time
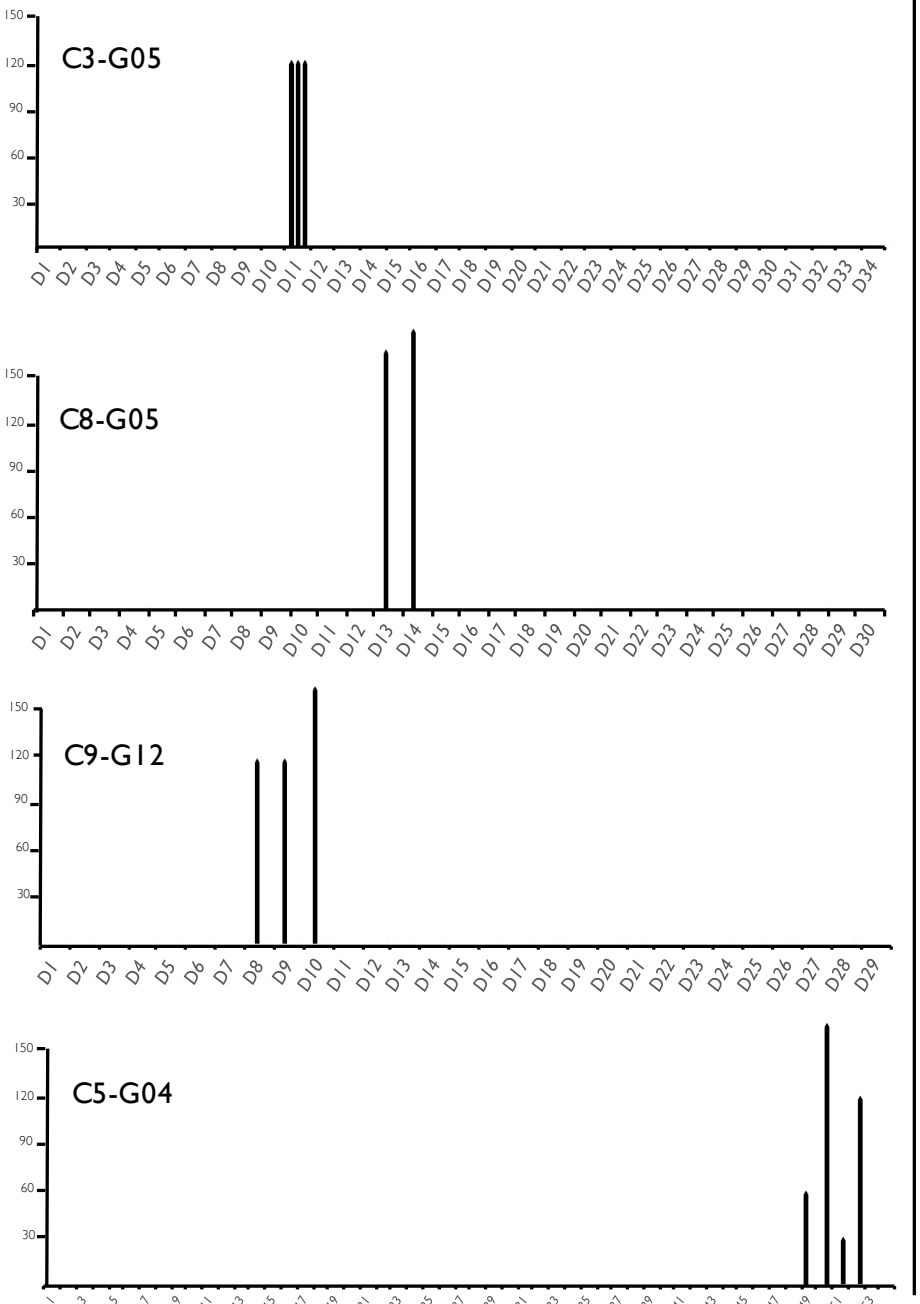

Characteristic rhythm: Shorter interactions, scattered over multiple phases of the project
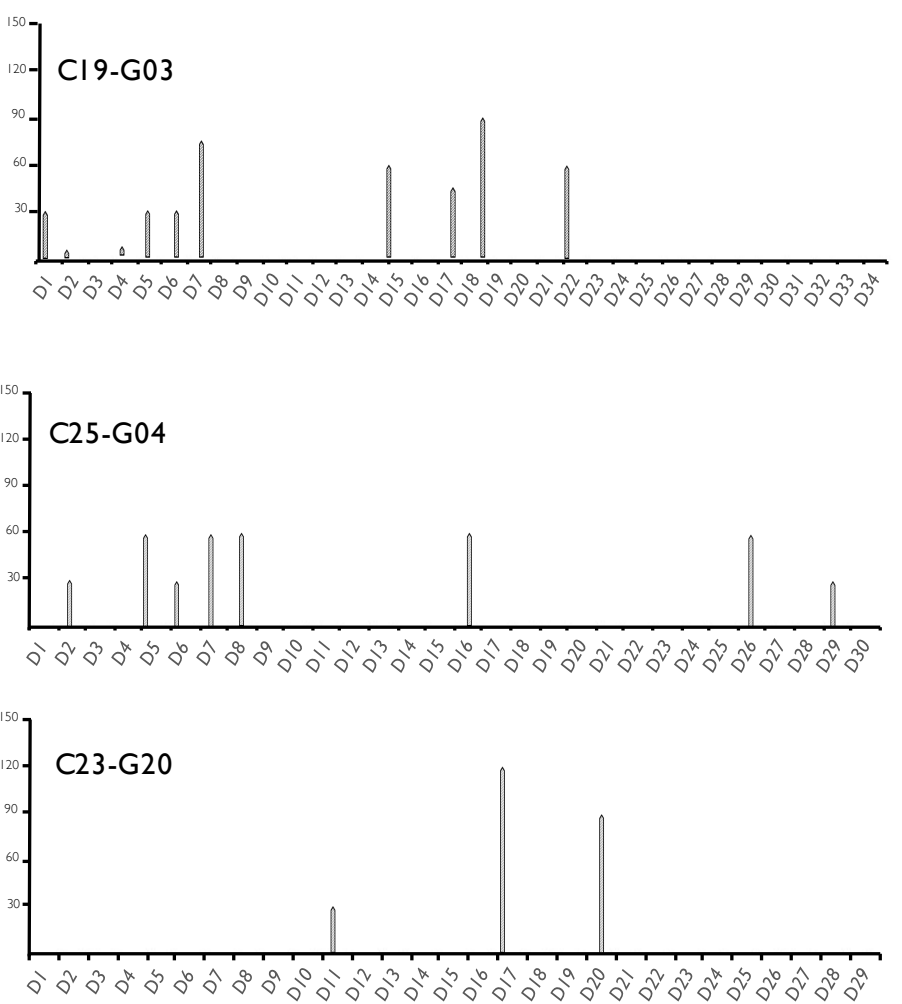

Cl7-G08

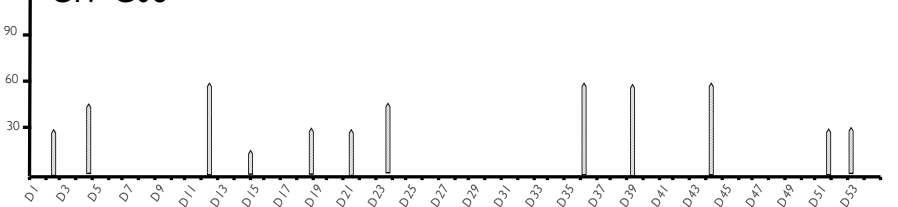

Notes: All data comes from Round 2 of data collection. Each chart illustrates the pattern of interactions between team members and a single giver over the course of the project. The Xaxis shows workdays elapsed; the Y-axis shows the interaction's duration in minutes of the interaction. Client meetings and workshops are excluded from the diagrams. When a given project had multiple guides or multiple path-clearers, we chose one representative giver of each type to depict. For each of the 4 projects, some guides also had a small number (2-4) of much shorter interactions with the team that are omitted here. Case numbers correspond to the sequence presented in Table 2; givers are identified by the unique numbers used throughout the manuscript. For instance, CI9-G03 signifies Case 19, Giver 03 


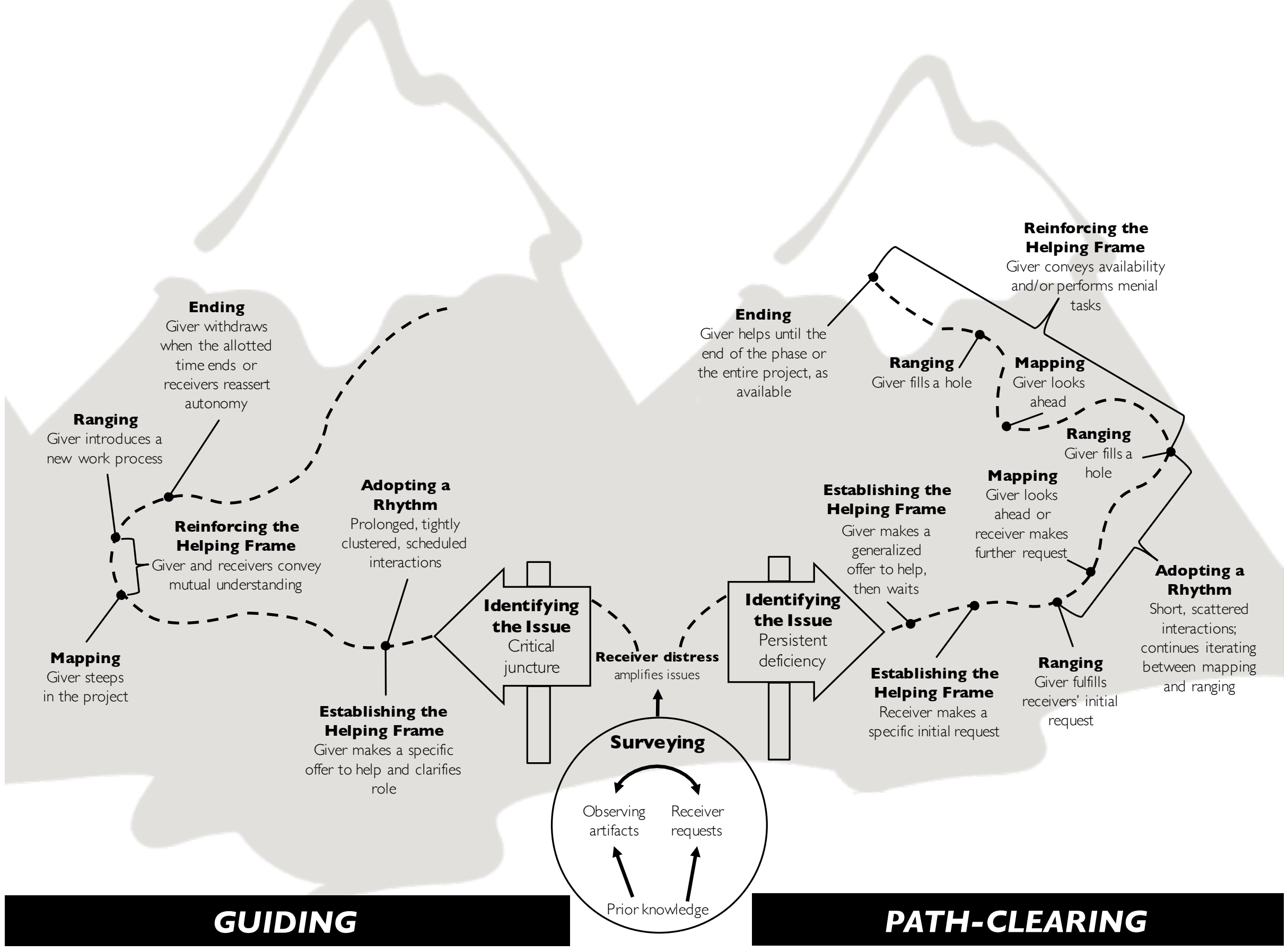




\section{Appendix A: Round 2 Interview Protocol}

1. Before asking about helping events, read the "work I did" portion. If elaboration is necessary, ask them to provide a general overview of the main project work that day.

2. Ask about help/non-help event(s) recorded in the daily diary texts.

If it was a HELPING EVENT:

- What happened, and who was involved?

- Who initiated this help? How did it come about?

- If the receiver initiated it, probe about the cues that help was needed, what help was needed, and who was needed.

- How long did it take for [giver's name] to help on this?

- Does [givers's name] have a formal role with this project? Will he/she continue to be involved going forward?

On a 7-point scale, how helpful was the help for your work on this project?

- If they don't offer up an explanation immediately, probe about WHY the help was useful (freed up time for other activities/helped make significant progress/made feel emotionally better, etc.).

If it was a NON-HELPING EVENT:

- What happened, and who was involved?

- Did you (or anyone) ask for help, or seek it in some way?

- If yes, probe about their cues that help was needed, what help was needed, and who was needed.

- On a 7-point scale, how much did the lack of help impede your work on this project?

- If they don't offer up an explanation immediately, probe about WHY the non-help impeded (took away time for other things, necessary to move forward in project work, made feel emotionally worse, etc).

3. AFTER covering each event from the week, general questions:

- Was there any other help you needed this week that you didn't get? Did you try to get this help?

- On a 1-7 scale, to what extent is your work on this project "on target" (i.e., you are making the necessary progress for your work to be successful)? To what extent is the team on target?

- On a 1-7 scale, how creative was your work on the project this week? How creative was the team's work?

- What percent of your time did you spend on the project this week?

- Any noteworthy changes in the project this week, or anything else you want me to know from the week? 


\section{Appendix B: Round 3 Critical-Incident Interview Protocol}

Informants were given the option to be interviewed as either givers or receivers. After they made this selection, they were asked about both a helpful and unhelpful experience in their chosen role. The paragraph that follows offers several alternative choices of wording. When interviewing respondents, we used the wording appropriate to the respondent's chosen role (giver or receiver) assessment of the helping episode

"Think of a specific incident at Glow when you successfully helped a team/were unsuccessful at helping a team/were part of a team that got especially helpful help/were part of a team that received not very helpful help. Features of this incident: (a) It's a specific incident (either very brief or extended over a day or more) rather than general helping over time; (b) You remember the incident well (so it probably happened recently); (c) You were not/Your team received help from someone who was not a core team member (at least not when this incident occurred); (d) You interacted directly with team members /the helper (rather than exclusively with the client or behind the scenes); (e) You believe that what you did helped the team/what you did was not helpful to the team/this person's help helped your team /this person's help was not very helpful to you or your team. Take a minute, if you need it, to think of an incident and try to remember it clearly."

1. Check incident: "Please give me a 30-second overview of the helping incident—what, at a very high level, was the issue, and what did you do to help?" Check the event by asking about each of the criteria above immediately after the 30 -second overview (i.e., specific incident/ remembered/ not core team member/ interacted with team/ helpful. If it does not appear to meet the criteria, search for a different event.

2. Start interview cue: "We are really interested in how this incident looked to you at the time, rather than what you think about it now. (We'll get to that at the end, if there is time.) Thus, if you start talking about what you think of the event now, I may stop you and ask you to focus more on your behaviors, thoughts, and feelings at the time. Some of the questions may seem a little mundane or repetitive, but this technique helps us get unique data about these helping incidents."

3. Project timeline and background: "Before we get into the helping event, I'll need a little background on the project itself. What was the project? Who was involved/ for how long/when did this event take place?" Ask the respondent to draw a timeline and locate the event on it, if they'd like. Make sure you know the characters and their formal roles, the month and year of the project start/end, and the specific point on the project timeline when the event occurred.

4. Helping-incident headline: "Now let's talk more specifically about the helping event. Set the stage for me: if this was a newspaper article about the helping incident, what would the headline be?" Make sure the participant's role is clear, and what the nature of the helping was.

5. Helping-incident milestones: "When did this incident begin (i.e., when did you first have a hint you might need to help)? When did it end? How long was the total time frame of this event? What are some of the important things that happened in between? If this was a 3-bullet-point summary, what would those points be?" Indicate the events on the timeline or ask the respondent to do so.

6. Flesh out the incident in detail, starting at the beginning: "Starting at the beginning: You said you first had a hint [that the team might need help] when [beginning cue]. Take me back to that point in time and describe the situation for me more specifically. What exactly did you do, and what did the others do? What were you thinking then? What were you feeling?" Repeat along these lines, hitting bullets, until you have covered the entire event.

7. Outcome of the incident: "How helpful was the help for the team's/your work on this project? Why do you think it was helpful?/Was this attempt at help harmful to the team's/your work, or just not very helpful? To what degree?" 
Colin M. Fisher (colin.fisher@ucl.ac.uk) is an Assistant Professor of Organisations and Innovation at University College London. He received his Ph.D. in Organizational Behavior from Harvard University. His research deals with collaboration and temporal dynamics (i.e., timing, rhythm, development over time) in three areas: (1) leading, helping, and coaching teams, (2) collective creativity and improvisation, and (3) group decision-making and negotiations.

Julianna Pillemer (pillemer@wharton.upenn.edu) is a Doctoral Candidate in Management at The Wharton School at the University of Pennsylvania. She studies the complexities of close relationships at work, and how new forms of working and technology are shaping how we present ourselves and relate to others.

Teresa M. Amabile (tamabile@hbs.edu) is Baker Foundation Professor and Edsel Bryant Ford Professor of Business Administration, Emerita, at Harvard Business School. She studies creativity, innovation, motivation, and the psychology of everyday work life. Her current research program investigates decisions about, attitudes toward, and adjustment to retirement. 